\title{
Corporate Policies of Republican Managers
}

\author{
Irena Hutton, Danling Jiang, and Alok Kumar*
}

\begin{abstract}
We demonstrate that personal political preferences of corporate managers influence corporate policies. Specifically, Republican managers who are likely to have conservative personal ideologies adopt and maintain more conservative corporate policies. Those firms have lower levels of corporate debt, lower capital and research and development (R\&D) expenditures, less risky investments, but higher profitability. Using the 9/11 terrorist attacks and Sept. 2008 Lehman Brothers bankruptcy as natural experiments, we demonstrate that investment policies of Republican managers became more conservative following these exogenous uncertainty-increasing events. Furthermore, around chief executive officer (CEO) turnovers, including CEO deaths, firm leverage policy becomes more conservative when managerial conservatism increases.
\end{abstract}

\section{Introduction}

Conservatism is one of the hallmarks of the Republican Party. According to a recent Gallup poll, $73 \%$ of Republicans identify themselves as conservative, $24 \%$ as moderate, and only $3 \%$ as liberal. ${ }^{1}$ In contrast, the Democratic Party adopts a more liberal platform and Democrats hold a relatively moderate political ideology. The same Gallup poll reports that $22 \%$ of Democrats are conservative, $40 \%$ associate themselves with a moderate ideology, and $38 \%$ are liberal.

If political conservatism translates into conservative attitudes in other domains, political ideology of individuals could influence various dimensions

\footnotetext{
*Hutton, ihutton@fsu.edu, Jiang, djiang@fsu.edu, College of Business, Florida State University, PO Box 3061110, Tallahassee, FL 32306; and Kumar, akumar@miami.edu, School of Business Administration, University of Miami, PO Box 248027, Coral Gables, FL 33124. We thank James Ang, Warren Bailey, Malcolm Baker, Jason Barabas, Yosef Bonaparte, Laurent Calvet, Sudheer Chava, Vidhi Chhaochharia, Thomas Chemmanur, Jeffrey Coles, Henrik Cronqvist, Werner DeBondt, Mara Faccio, Carola Frydman, John Graham, Dirk Hackbarth, Gilles Hilary, David Hirshleifer, David Hutton, Narasimhan Jegadeesh, Jonathan Karpoff, Markku Kaustia, Han Kim, George Korniotis, Leonard Kostovetsky (the referee), Alexander Ljungqvist, Angie Low, Paul Malatesta (the editor), Alexandra Niessen, Jeremy Page, Carrie Pan, Joel Peress, Jay Ritter, Oliver Spalt, Siew Hong Teoh, and seminar participants at Florida State University, 2010 Center for Research in Security Prices (CRSP) Forum, and 2011 American Finance Association (AFA) Meetings for helpful discussions and valuable comments. We are grateful to Henrik Cronqvist, Anil Makhija, and Scott Yonker for providing the chief executive officer (CEO) home leverage data. We also thank Morgan Bender, Jon Burns, Steve Creasy, Kyle Lahtinen, and Jillian Schrier for excellent research assistance. We are responsible for all remaining errors and omissions.

${ }^{1}$ See http://www.gallup.com/poll/120857/conservatives-single-largest-ideological-group.aspx
} 
of their economic behavior, including the degree of their financial conservatism. Recent studies in finance show that personal political preferences influence investment decisions of individual investors (Kaustia and Torstila (2011), Bonaparte, Kumar, and Page (2012)) and money managers (Hong and Kostovetsky (2012)), as well as forecasting activities of equity analysts (Jiang, Kumar, and Law (2014)). Motivated by these related studies, we examine whether the political orientation of top corporate managers can partially explain, at least, the significant heterogeneity in firm capital structure and investment policies.

Our key conjecture is that Republican-leaning managers, who tend to have conservative personal ideologies, are more likely to adopt financially conservative policies. Although there are Republican managers who are known for riskier corporate policies, on average, Republican managers have more conservative corporate policies than non-Republican managers. Specifically, we posit that firms with Republican managers have less debt than comparable firms with non-Republican managers. ${ }^{2}$ Furthermore, firms with Republican managers invest less in tangible assets and research and development (R\&D) and choose safer investments, which, in the short run, may positively influence profitability.

To test these conjectures, we use personal political contributions of corporate managers to identify their political orientation and degree of financial conservatism. Our identification strategy is similar to that of Hong and Kostovetsky (2012), who use political contributions provided by the Federal Election Commission (FEC) to infer the political orientation of money managers and its impact on portfolio choices. Before using political contributions-based measures to study the relation between political orientation and corporate policies, we confirm that political contributions of managers reflect their personal political orientation and can serve as a good proxy for the level of their financial conservatism.

First, using a subset of chief executive officers (CEOs) that self-report their political affiliations, we find a significant positive correlation between our measure of political orientation and the self-reported political orientation. ${ }^{3} \mathrm{Next}$, we show that older, male, and nonminority managers that are demographically similar to the Republican electorate are significantly more likely to be classified as Republicans using our measure. Last, we demonstrate that managers classified as Republicans exhibit greater debt aversion than managers classified as Democrats in their personal leverage choices made at the time of the purchase of their primary homes. ${ }^{4}$ These results further suggest that our political orientation measure is likely to capture financial conservatism of corporate managers reasonably well.

In our main empirical analyses, using the political contributions-based proxy for managerial conservatism, we estimate a series of policy regressions and show that firms with Republican managers have significantly lower levels of corporate

\footnotetext{
${ }^{2}$ In unreported analyses, we find no systematic differences in firm policies between firms with Democratic managers and those with politically neutral managers. This is consistent with a relatively moderate ideology of Democrats. Thus, we do not differentiate between Democratic and politically neutral managers and call them "non-Republican."

${ }^{3}$ We are able to obtain self-reported political orientation measures for 640 CEOs from the Marquis Who's Who database and Internet searches of CEO biographies.

${ }^{4}$ The home leverage data are from Cronqvist, Makhija, and Yonker (2012). We are grateful to Henrik Cronqvist, Anil Makhija, and Scott Yonker for providing the CEO home leverage data.
} 
debt, lower capital and R\&D expenditures, less risky investments, and higher profitability. These policy regression estimates indicate that having conservative managers generates higher profitability, at least in the short run. However, this benefit comes at the cost of reduced investment, which may affect firm growth and profitability in the long run.

In our subsequent empirical tests, we show that managerial conservatism can "cause" firms to adopt conservative policies. Our identification strategy for establishing this causal effect focuses on natural experiments in which exogenous shocks greatly increase market uncertainty and force managers to respond to them. We conjecture that conservative CEOs will take more defensive actions in response to elevated levels of market uncertainty. Using the terrorist attacks in Sept. 2001 and the collapse of Lehman Brothers in Sept. 2008 as natural experiments, we demonstrate that Republican CEOs respond to these exogenous uncertainty-increasing events by cutting investments in the subsequent quarters significantly more than otherwise similar firms in the same industry run by Democratic or moderate CEOs.

Beyond these two marketwide shocks, we use CEO turnover as a form of firm-specific shock to investigate whether managers actively adjust leverage in a manner consistent with their personal political values. Specifically, we observe a decline in firm leverage when a more conservative CEO replaces a less conservative manager. This finding holds for the full sample of turnover events as well as subsamples that exclude poorly performing firms in which CEO turnover may coincide with necessary capital structure changes. The results are also similar when we include only firms with long-term predecessor CEOs as a proxy for established policies or include only exogenous turnover events induced by CEO death. ${ }^{5}$ The evidence from both marketwide and firm-specific shocks suggests that top managers can play an active role in shaping firm policies based on their personal financial conservatism.

A key alternative explanation for our findings is that instead of serving as a proxy for managerial political preferences, our political contributions-based measure may capture political connections of managers. Thus, our results could reflect the benefits of strategic donations and political connections (e.g., Cooper, Gulen, and Ovtchinnikov (2010)). This political favors-based hypothesis is unlikely to explain our findings, because it is not immediately obvious why the majority of managers $(71 \%)$ consistently contribute only to one political party instead of strategically switching donations. ${ }^{6}$ Second, it is unclear why political connections to the Republican Party generate conservative corporate policies, while connections to the Democratic Party produce opposite outcomes. Even when we

\footnotetext{
${ }^{5}$ For CEO death-induced turnover events, this result is economically significant but statistically weak due to the small sample size. See Section VI.A.3 for additional details.

${ }^{6}$ Ansolabehere, de Figueiredo, and Snyder (2003) suggest that political contributions are commonly used to express one's political orientation and ideology rather than to establish political connections. They find that the political contribution limits are not reached in most cases, and, on average, top corporate executives contribute less than $0.05 \%$ of their annual compensation. Recent research in political science also supports the view that campaign contributions are unlikely to facilitate political connections. Those connections are instead formed mainly through direct lobbying activities (Groseclose, Milyo, and Primo (2000)).
} 
use several proxies (including the state-fixed effects) to explicitly account for the effects of political connections on corporate policies or exclude contributions to incumbent politicians, we continue to find a strong relation between managers' political orientation and firm policies. Thus, our findings are unlikely to reflect the impact of political connectedness on corporate policies.

Overall, our results contribute to the fast growing finance literature on managerial attributes. This literature demonstrates that various managerial characteristics, including overconfidence (Malmendier and Tate (2005)), personal risk preferences (Chava and Purnanandam (2010)), military background (Benmelech and Frydman (2014)), life experiences (Malmendier, Tate, and Yan (2011)), height and beauty (Graham, Harvey, and Puri (2010), (2013)), and, more generally, managerial-fixed effects (Bertrand and Schoar (2003)) are important determinants of firm policies. To our knowledge, this is the first study that directly measures political preferences of a large, comprehensive sample of corporate managers and shows that political preferences help explain leverage choices and investment policies.

Our study also contributes to a small but growing finance literature on behavioral consistency. The theory of behavioral consistency posits that individuals exhibit stable behavioral dispositions across various domains, contexts, and situations (Epstein (1979), Funder and Colvin (1991)). Recent finance studies provide evidence of behavioral consistency in corporate decisions, where behavioral patterns of managers are identified based on personal home mortgage leverage (Cronqvist et al. (2012)), personal tax decisions (Chyz (2013)), and sensation seeking proxied by a pilot license (Cain and McKeon (2014)). In contrast to these studies, we examine whether the personal ideologies of managers, as captured by their political orientation, influence corporate policies. ${ }^{7}$

The rest of the paper is organized as follows. The next section summarizes the related literature that motivates our study. Section III describes the data sources and the key political orientation measures. Section IV demonstrates that the political orientation measures capture financial conservatism reasonably well. We present our main empirical results in Sections V and VI and examine alternative explanations for our findings in Section VII. We conclude in Section VIII with a brief discussion.

\section{Why Should Managerial Political Orientation Matter?}

Our empirical analysis is based on the fundamental premise that political orientation of managers is correlated with their financial conservatism. This correlation is likely to be induced by their personal ideologies and values, which determine both the direction of political orientation and the degree of financial conservatism. In this section, we summarize evidence from the related literature in psychology and political science that provides the foundation for the proposed links between personal ideology, political orientation, and financial conservatism.

\footnotetext{
${ }^{7}$ In a related recent study, Di Giuli and Kostovetsky (2014) show that firms with Democratic political environments choose more socially responsible policies. This study, however, does not examine the relation between managerial political orientation and firm capital structure and investment policies.
} 
Ideology refers to the belief system that captures one's values and shapes opinions and attitudes toward various aspects of society and its customs and institutions, ranging from politics and economics to religion (Converse (1964), Jost (2006)). While ideology is a multidimensional concept, many individuals self-identify along the liberal-conservative or left-right continuum, because their stand on many issues can be described from that perspective. The key differences between the two ideological extremes are related to openness to change (Conover and Feldman (1981)). Specifically, individuals with a conservative ideology prefer familiar versus unfamiliar stimuli (Glasgow and Cartier (1985)); are less likely to engage in sensation-seeking behavior (Kish, Netterberg, and Leahy (1973)); value job security over task variety (Atieh, Brief, and Vollrath (1987)); exhibit greater aversion to ambiguity, uncertainty, and complexity (Wilson (1973), Gillies and Campbell (1985), McAllister and Anderson (1991)); and are more sensitive to the possibility of a loss (Wilson (1973)). These personality traits also serve as important determinants of various economic and financial decisions. Indeed, recent research in psychology and political science shows that conservative individuals fear losses and value financial security (Jost, Glaser, Kruglanski, and Sulloway (2003)).

Personal ideology often manifests itself in political values, where the conservatives tend to favor the core values of the Republican Party, particularly since the 1970s (Abramowitz and Saunders (2006)). In addition to the evidence from a recent Gallup survey discussed in Section I, a strong link between the Republican ideology and conservatism is also a widely held belief among U.S. voters. According to the American National Election Studies, Americans consistently perceive Republicans to be more conservative. During the 1960-2008 period, about $44 \%-68 \%$ of individuals held the belief that Republicans are more conservative than Democrats and only $9 \%-18 \%$ of survey participants thought that Democrats exhibit greater conservatism. ${ }^{8}$ Overall, the evidence from various surveys indicates that the typical Republican is likely to be more conservative than the typical Democrat.

Given the link between personal ideology and political preferences and the link between personal ideology and financial conservatism, we expect political preferences and financial conservatism to be related. As a result, financial conservatism, as revealed through political preferences, could be a reasonable predictor of management style. Even when managers attempt to maximize shareholder value, variation in political preferences could lead to systematic variation in perceptions of downside risk and growth opportunities. This argument does not necessarily imply an agency problem, but merely posits that managers' decisions are influenced by their personality traits.

In particular, due to their conservative personality traits, Republican managers are likely to be more risk averse and debt averse than Democratic or moderate managers in their financial decisions. ${ }^{9}$ Consequently, Republican managers may be more cautious in their use of debt and investment in risky projects.

\footnotetext{
${ }^{8}$ See http://www.electionstudies.org/nesguide/toptable/tab3_2.htm

${ }^{9}$ Using a risk tolerance measure that captures an individual's attitude toward risk, Kam and Simas (2010) show that Republicans have significantly lower levels of risk tolerance than Democrats.
} 
Conditional upon taking risk, Republican managers are likely to choose smaller and safer bets, which would be associated with lower levels of investment in tangible assets and R\&D as well as lower volatility of stock returns. Such conservative investment choices may also impact profitability. In Section III, we describe the data sets used to test the relation between political orientation of managers and these corporate policies.

\section{Measures of Political Orientation}

We use data from multiple sources to identify managers and their political orientation. Our main sample of firms and managers is from the ExecuComp database and covers the period from 1992 to 2008. We exclude utilities (Standard Industrial Classification (SIC) codes between 4900 and 4999) and financials (SIC codes between 6000 and 6999), since these industries are more subject to regulation and managers have less discretion in their choice of leverage and some firm policies.

To identify political preferences of managers, we focus on the top five executives based on their annual ExecuComp reported salary levels. ExecuComp provides the full name and title of top managers for each fiscal year, which we use to identify their individual political contributions recorded by the FEC.

In addition to ExecuComp, we obtain firm-level accounting variables from Compustat. Firm-level return volatility is computed using daily stock returns obtained from the Center for Research in Security Prices (CRSP). Some of our tests use CEO age and gender from ExecuComp and self-reported party affiliations and demographic attributes of a subset of CEOs from the 2009 version of the Marquis Who's Who database and various Internet sources.

\section{A. Political Contributions Data}

We identify the political orientation of managers using their financial contributions to Republican- and Democratic-affiliated Senate, House, and presidential candidates, and party committees in political campaigns covering the 1991-2008 period. These committees are established by candidates and political parties to collect and manage campaign funds. The financing of federal elections is governed by the FEC. For contributions exceeding \$200, the FEC has made public the identities of the donors and contribution amounts, information about the committee recipients including their party affiliation, and statistics for aggregated contribution data at http://www.fec.gov.

Corporate managers can contribute indirectly through their own company political action committees (PACs) or directly through personal contributions to candidates or party committees. Only the second form of contributions allows us to identify the political orientation of managers, since company PACs usually

Furthermore, in the political arena, deficit and national debt reduction is one of the main goals of fiscally conservative politicians (Zelizer (2000)). 
contribute simultaneously to multiple parties (Cooper et al. (2010)). There are limits on political contributions of individuals that gradually increase over time. ${ }^{10}$

The FEC's individual contributions data contain the name, address, and occupation of the donor, the amount of the contribution, and the date of the contribution. Occupation usually includes the employer name and often the position and title of the individual, which together with the contributor's name and contribution date serve as the key mapping information used to link ExecuComp managers and FEC donors. Specifically, we map ExecuComp managers during a certain fiscal year to the most recent election cycle that contains the beginning of that fiscal year. For each political contribution, we use a computer-based matching algorithm to identify potential manager matches and then verify their correctness through visual inspection. We identify 49,722 eligible political donations made by 5,183 unique managers over the 1992 to 2008 sample period.

\section{B. Measuring Political Orientation of Managers and Firms}

To quantify political preferences of managers and firms, we begin by computing a manager-specific Republican dummy (REPDUMMGR) for each election cycle. This variable identifies strongly Republican managers and takes the value of 1 if the political contributions of a manager in a given election cycle are all directed toward the Republican Party, and 0 otherwise.

Next, we compute a manager-specific Republican index (REPMGR) as the mean value of REPDUMMGR across all election cycles in which that manager contributes. Similar to Hong and Kostovetsky (2012), we assign REPMGR a value of zero to managers who never make a political contribution. ${ }^{11}$ To illustrate, consider a manager who makes donations in five out of nine election cycles over our sample period. If he donates exclusively to the Republican party in all five cycles, his REPMGR will be $1(=5 / 5)$. However, if he donates exclusively to the Republican party in two of the five cycles with mixed donations to both parties in the remaining three cycles, his REPMGR will be $0.4(=2 / 5)$. Thus, REPMGR indicates the percentage of time a manager asserts a strong and active support for the Republican Party through political donations. ${ }^{12}$

The REPMGR estimate of a particular manager does not vary during the sample period, which captures the idea that party identification is developed and established in adolescence or early adulthood and remains stable during the entire adult life (Green, Palmquist, and Schickler (2002)). This method of measuring managerial political orientation also minimizes the potential noise introduced by variations in party popularity. However, this measure introduces a look-ahead bias. For robustness, we construct alternative measures based on the first or the

\footnotetext{
${ }^{10}$ For instance, in the 2009-2010 election cycle, individuals could contribute up to $\$ 2,400$ per candidate, $\$ 30,400$ per national party committee, and $\$ 5,000$ per PAC, not to exceed a $\$ 115,500$ limit on aggregate contributions.

${ }^{11}$ Our results hold if we exclude nondonor managers from our sample.

${ }^{12}$ For robustness, we also consider a continuous measure of the manager-level Republican index (RELREPMGR), based on the difference in contributions to the Republican and Democratic parties divided by the sum of contributions to both parties in a given election cycle. The details are available in the Online Appendix (www.jfqa.org).
} 
prior donations of managers up to the current fiscal year and find mostly similar results. Additional details about these measures are available in the Online Appendix (www.jfqa.org).

Last, we compute the firm-level Republican index (REP) by aggregating REPMGR measures for a given firm. During the aggregation, managers are assigned weights that vary inversely with the ExecuComp salary rank to reflect their relative importance within the firm. ${ }^{13}$ That is, the highest paid manager, usually the CEO, is assigned a weight of $\omega$, while the second highest paid manager, usually the chief financial officer (CFO), is assigned a weight of $0.5 \omega$, and so forth. Unlike REPMGR, REP varies over time as the firm-level managerial composition changes. In robustness tests, we also consider REP constructed only with the political orientation of the firm's CEO (i.e., $\mathrm{REP}_{\mathrm{CEO}}$ ).

The resulting Republican index REP ranges from 0 to 1 , where 1 indicates that firm managers are strong supporters of the Republican Party. In contrast, zero REP indicates that managers either have moderate or Democratic political preferences, do not make political contributions at all, or choose to contribute in ways that are not recorded by the FEC. In the interest of brevity, we loosely refer to firms with zero REP as non-Republican.

\section{Political Orientation Measures: Summary Statistics}

Panel A of Table 1 reports the summary statistics for the annual managerial political contributions across all election cycles. We find that during the full sample period, 5,183, or $19.57 \%$ of the top five ExecuComp managers, made at least one political contribution, and they are classified as "donors." A donor manager makes an average contribution of $\$ 13,932$, of which $\$ 8,632$ is contributed to the Republican Party and \$5,300 to the Democratic Party.

Unlike firm PACs, which typically contribute to both Republican and Democratic parties in any election cycle, the majority of managers $(71.29 \%)$ consistently contribute to only one party. ${ }^{14}$ This consistency in managerial contributions indicates that while firms may donate to political parties strategically to seek political favors or to represent the political views of a diverse shareholder base, political contributions of managers are more likely to reflect their political orientation and could serve as a good proxy for their level of financial conservatism. We classify one-party contributors as "polarizers." These individuals favor the Republican Party, with $67.85 \%$ of polarizers contributing only to it.

Panel B of Table 1 reports summary statistics for the firm-level political orientation measures. After aggregating managers' political contributions to the firm level, we are able to obtain political orientation measures for 1,819 unique firms, which constitutes $75.63 \%$ of all firms covered by the ExecuComp during our sample period. The firm-level political orientation measures indicate that a larger proportion of firms have a Republican tilt as the REP estimates

\footnotetext{
${ }^{13}$ Our results are not sensitive to this aggregation scheme and remain qualitatively similar and statistically significant when we assign equal weights to the top five managers.

${ }^{14}$ See Cooper et al. (2010) for details about political contributions made by PACs.
} 
TABLE 1

Political Orientation of Managers and Firms: Descriptive Statistics

Panel A of Table 1 reports the descriptive statistics for donor managers during all election cycles from 1991 to 2008 Managers who make at least one political contribution to a party-affiliated committee in the election cycle are identified as donors. \%Donor (\%Don) is the percentage of the top five managers that donate in a given cycle. Mean\$ contribution is the average dollar contribution to party-affiliated committees per manager. Rep $\$$ and Dem $\$$ refer to dollar contributions to Republican- and Democratic-affiliated committees, respectively. Polarizer refers to managers who make all contributions to either Republican- or Democratic-affiliated committees in a given election cycle. \%Polarizer (\%Pol) is the total number of polarizers as a percentage of total number of donor managers. REPDUMMGR is the cycle-specific Republican dummy for donor managers, which takes the value of 1 when all donations of the manager go to the Republican Party in that cycle, and 0 otherwise. The 1991-2008 row reports the summary statistics for all unique donor managers. In Panel B, we report firm-level political orientation measures. For each manager, REP is defined as the mean REPDUMMGR across all election cycles, where nondonors are assigned a value of 0 . We then aggregate the top five managers' political orientation measures at the firm level by assigning weights that vary inversely with managers' pay rank. In this panel, firms with at least one manager who makes political contributions to party-affiliated committees in at least one election cycle are identified as donor firms. Donor (\%) is the percentage of donor firms in ExecuComp. In the 1992-2008 row, Donors refers to the number of unique donor firms. The sample period is from 1991 to 2008 . Additional details about all variables are available in the Appendix.

Panel A. Political Orientation of Managers

\begin{tabular}{|c|c|c|c|c|c|c|c|c|c|c|}
\hline \multirow[b]{2}{*}{ Cycle } & \multirow[b]{2}{*}{ All } & \multicolumn{2}{|c|}{ Donors (3-4) } & \multicolumn{3}{|c|}{ Contributions (5-7) } & \multicolumn{3}{|c|}{ Polarizer (8-10) } & \multirow{2}{*}{$\frac{\text { Cycle-Specific }}{\text { REPDUMMGR }}$} \\
\hline & & $N($ Don $)$ & \%Don & Mean\$ & Rep\$ & Dem\$ & $N($ Rep) & $\mathrm{N}(\mathrm{Dem})$ & $\% \mathrm{Pol}$ & \\
\hline 1 & 2 & 3 & 4 & 5 & 6 & 7 & 8 & 9 & 10 & 11 \\
\hline 1991-1992 & 2,776 & 447 & 16.10 & $\$ 3,581$ & $\$ 2,459$ & $\$ 1,122$ & 233 & 124 & 79.87 & 0.52 \\
\hline 1993-1994 & 7,631 & 891 & 11.68 & $\$ 3,749$ & $\$ 1,775$ & $\$ 1,973$ & 407 & 359 & 85.97 & 0.46 \\
\hline 1995-1996 & 8,823 & 1,229 & 13.93 & $\$ 4,715$ & $\$ 3,206$ & $\$ 1,509$ & 794 & 231 & 83.40 & 0.65 \\
\hline 1997-1998 & 9,520 & 961 & 10.09 & $\$ 4,219$ & $\$ 2,377$ & $\$ 1,842$ & 532 & 289 & 85.43 & 0.55 \\
\hline 1999-2000 & 9,726 & 1,489 & 15.31 & $\$ 5,740$ & $\$ 3,783$ & $\$ 1,957$ & 933 & 292 & 82.27 & 0.63 \\
\hline 2001-2002 & 9,089 & 1,005 & 11.06 & $\$ 4,325$ & $\$ 2,562$ & $\$ 1,763$ & 487 & 343 & 82.59 & 0.48 \\
\hline 2003-2004 & 9,107 & 1,587 & 17.43 & $\$ 10,724$ & $\$ 7,172$ & $\$ 3,552$ & 934 & 368 & 82.04 & 0.59 \\
\hline 2005-2006 & 9,237 & 1,144 & 12.38 & $\$ 10,495$ & $\$ 6,870$ & $\$ 3,625$ & 624 & 301 & 80.86 & 0.55 \\
\hline 2007-2008 & 7,685 & 1,430 & 18.61 & $\$ 10,839$ & $\$ 5,863$ & $\$ 4,976$ & 614 & 454 & 74.69 & 0.57 \\
\hline $1991-2008$ & 26,479 & 5,183 & 19.57 & $\$ 13,932$ & $\$ 8,632$ & $\$ 5,300$ & 2,507 & 1,188 & 71.29 & 0.55 \\
\hline \multicolumn{11}{|c|}{ Panel B. Political Orientation of Firms } \\
\hline Fiscal Year & & All Firms & & Donors & & Donor (\%) & & REP: All & & REP: Donors \\
\hline 1 & & 2 & & 3 & & 4 & & 5 & & 6 \\
\hline 1992 & & 893 & & 547 & & 61.25 & & 0.27 & & 0.42 \\
\hline 1993 & & 1,211 & & 811 & & 66.97 & & 0.22 & & 0.33 \\
\hline 1994 & & 1,342 & & 928 & & 69.15 & & 0.22 & & 0.31 \\
\hline 1995 & & 1,430 & & 984 & & 68.81 & & 0.22 & & 0.32 \\
\hline 1996 & & 1,528 & & 1,050 & & 68.72 & & 0.22 & & 0.32 \\
\hline 1997 & & 1,580 & & 1,091 & & 69.05 & & 0.22 & & 0.32 \\
\hline 1998 & & 1,613 & & 1,115 & & 69.13 & & 0.22 & & 0.31 \\
\hline 1999 & & 1,575 & & 1,117 & & 70.92 & & 0.22 & & 0.31 \\
\hline 2000 & & 1,497 & & 1,084 & & 72.41 & & 0.21 & & 0.30 \\
\hline 2001 & & 1,474 & & 1,076 & & 73.00 & & 0.22 & & 0.30 \\
\hline 2002 & & 1,499 & & 1,089 & & 72.65 & & 0.22 & & 0.30 \\
\hline 2003 & & 1,531 & & 1,106 & & 72.24 & & 0.21 & & 0.29 \\
\hline 2004 & & 1,498 & & 1,086 & & 72.50 & & 0.21 & & 0.29 \\
\hline 2005 & & 1,404 & & 1,023 & & 72.86 & & 0.21 & & 0.28 \\
\hline 2006 & & 1,483 & & 1,056 & & 71.21 & & 0.19 & & 0.27 \\
\hline 2007 & & 1,419 & & 978 & & 68.92 & & 0.18 & & 0.26 \\
\hline 2008 & & 1,240 & & 835 & & 67.34 & & 0.17 & & 0.25 \\
\hline 1992-2008 & & 2,405 & & 1,819 & & 75.63 & & 0.21 & & 0.30 \\
\hline
\end{tabular}

(see columns 5 and 6) are positive. Specifically, the full sample average REP is 0.21 when we consider all ExecuComp firms and 0.30 when we consider only firms with at least one donor manager. ${ }^{15}$

\footnotetext{
${ }^{15}$ Because the political orientation of nondonor managers is coded as 0 , the firm-level REP averages reported in columns 5 and 6 of Panel B of Table 1 are considerably lower than the manager-level REPDUMMGR values reported in column 11 of Panel A. This evidence does not indicate that firmlevel political orientations are weaker than manager-level political orientations.
} 
Panel A of Table 2 reports summary statistics for several firm-level political orientation measures. These statistics confirm that firms have a greater proportion of Republican managers. The mean of REP is 0.211 (median is 0.109 ), with a standard deviation of 0.249. This evidence indicates that, on average, firms are tilted toward the Republican Party. Examining the CEO level measure, we find that $\mathrm{REP}_{\mathrm{CEO}}$ is even more skewed toward the Republican Party. The mean value of $\mathrm{REP}_{\mathrm{CEO}}$ is 0.297 and the median is 0 .

TABLE 2

Summary Statistics for Main Variables

Panel A of Table 2 reports firm-level political orientation measures. REP is the Republican index based on the donations of the firm's top five managers, and REP ${ }_{\text {CEO }}$ is based on the contributions of the firm's CEO. We report the summary statistics for the main dependent variables in Panel B and for the main independent variables in Panel C. Additional details about these variables are available in the Appendix. The sample period is from 1992 to 2008.

\begin{tabular}{|c|c|c|c|c|c|c|}
\hline Variable & $N$ & Mean & $\begin{array}{l}\text { Standard } \\
\text { Deviation }\end{array}$ & $\begin{array}{c}\text { 25th } \\
\text { Percentile } \\
\end{array}$ & Median & $\begin{array}{c}\text { 75th } \\
\text { Percentile } \\
\end{array}$ \\
\hline \multicolumn{7}{|c|}{ Panel A. Firm-Level Political Orientation } \\
\hline REP & 24,195 & 0.211 & 0.249 & 0.000 & 0.109 & 0.584 \\
\hline REPCEO & 21,808 & 0.297 & 0.415 & 0.000 & 0.000 & 1.000 \\
\hline \multicolumn{7}{|c|}{ Panel B. Dependent Variables } \\
\hline TDA & 24,217 & 0.214 & 0.188 & 0.000 & 0.196 & 0.458 \\
\hline LDA & 24,217 & 0.181 & 0.174 & 0.000 & 0.154 & 0.413 \\
\hline TDM & 24,217 & 0.181 & 0.209 & 0.000 & 0.111 & 0.489 \\
\hline LDM & 24,217 & 0.154 & 0.187 & 0.000 & 0.083 & 0.427 \\
\hline INV & 24,217 & 0.254 & 0.171 & 0.076 & 0.209 & 0.492 \\
\hline R\&D & 24,217 & 0.034 & 0.063 & 0.000 & 0.000 & 0.114 \\
\hline VOL & 23,549 & 0.029 & 0.015 & 0.015 & 0.026 & 0.048 \\
\hline $\mathrm{ROA}$ & 24,217 & 0.014 & 0.183 & -0.102 & 0.050 & 0.132 \\
\hline \multicolumn{7}{|c|}{ Panel C. Control Variables } \\
\hline $\mathrm{MB}$ & 24,217 & 1.704 & 1.663 & 0.436 & 1.221 & 3.373 \\
\hline LOGASSET & 24,217 & 6.727 & 1.714 & 4.630 & 6.649 & 9.051 \\
\hline PROFIT & 24,217 & 0.127 & 0.136 & 0.015 & 0.140 & 0.257 \\
\hline TANG & 24,217 & 0.289 & 0.219 & 0.050 & 0.233 & 0.626 \\
\hline LOSS & 24,217 & 0.182 & 0.386 & 0.000 & 0.000 & 1.000 \\
\hline LAGTDA & 24,217 & 0.212 & 0.187 & 0.000 & 0.192 & 0.454 \\
\hline CONNECT & 24,142 & 0.599 & 1.790 & 0.000 & 0.000 & 1.549 \\
\hline
\end{tabular}

\section{Validation Tests}

Before using the firm-level political orientation measure to study the relation between political orientation and corporate policies, we conduct several tests to validate its effectiveness as a proxy for financial conservatism.

\section{A. Revealed versus Self-Reported Political Orientations}

In the first test, we examine the relation between managers' self-reported party affiliations and our political orientation proxies. Using the 2009 version of the Marquis' Who's Who database and various Internet sources, we are able to identify 640 CEOs from our sample who self-report as either Republicans or Democrats.

We find that our measure of political preferences is highly correlated with the self-reported political orientation measure. The correlation between our CEO-level 
Republican index $\left(\mathrm{REP}_{\mathrm{CEO}}\right)$ and the self-reported Republican dummy (with self-reported Democrats designated a value of 0$)$ is $0.44(p<0.001)$. The correlation between the Democratic index $\left(\mathrm{DEM}_{\mathrm{CEO}}\right)$ and the self-reported Democratic dummy is $0.53(p<0.001)$, where DEM $_{\mathrm{CEO}}$ captures the percentage of time a CEO asserts strong and active support for the Democratic Party through political donations. These results confirm our key assumption that measures of managers' political orientation based on their political donations are likely to reflect their self-reported political identities.

\section{B. Political Orientation and CEO Characteristics}

In the second test, we link our measure of political preferences to the CEOs' demographic profiles. We collect CEO attributes such as gender, age, whether the CEO is a minority (nonwhite) and has served in the military from ExecuComp, and various Internet sources. These variables are motivated by prior literature and survey results, which show that male, older, and white individuals are more likely to identify with the Republican Party. We are able to match 1873 donor CEOs in our sample with these demographic data.

Consistent with this prior evidence, we find that our CEO-level Republican index is highly and significantly correlated with these attributes. In particular, Republican-leaning CEOs are likely to be male, older, but less likely to be a minority. The correlations between $\mathrm{REP}_{\mathrm{CEO}}$ and the male, age, and minority dummies are $0.085,0.050$, and -0.067 , respectively, with $(p<0.001)$. This evidence further strengthens our conjecture that the Republican index captures managers' personal political beliefs.

\section{Political Orientation and Home Leverage}

In the third test, we examine whether Republican managers exhibit stronger debt aversion in their personal financial decisions than non-Republican managers. Specifically, we study CEO's personal leverage choices made during the purchase of their primary homes. Using the personal mortgage data collected by Cronqvist et al. (2012), we identify a sample of 330 CEOs with available political orientation and home leverage measures.

We find a negative but statistically insignificant correlation between $\mathrm{REP}_{\mathrm{CEO}}$ and the home leverage variable (correlation coefficient $=-0.049, p$-value $=$ 0.37). However, when we redefine our political orientation variable to describe the other end of the political spectrum, we find a marginally significant correlation between $\mathrm{DEM}_{\mathrm{CEO}}$ and the home leverage variable (correlation coefficient = 0.091, $p$-value $=0.099$ ). This evidence indicates that a strongly Democratic CEO is likely to choose greater home leverage than a Republican or moderate CEO.

Furthermore, in a subset of CEOs with 0 home leverage $(N=119)$, there are 46 strong Republicans $\left(\operatorname{REP}_{\mathrm{CEO}}=1\right)$ and 18 strong Democrats $\left(\mathrm{DEM}_{\mathrm{CEO}}=1\right)$, and the difference between the two proportions is statistically significant $(z$-statistic $=3.50, p$-value $<0.001)$. Taken together, these results indicate that Republican managers exhibit greater aversion to debt in their personal financial decisions than Democratic managers. 
Overall, the results from all three tests confirm that political contributionsbased measures capture managers' political orientation. These results also suggest that political values of managers are a predictor of their attitudes toward debt in personal finance settings.

\section{Political Orientation and Corporate Policies}

In this section, we present our first set of main results. Specifically, we examine whether firms with Republican managers have more conservative firm policies. We study leverage choices, capital, and R\&D investment decisions, as well as the outcomes of these policy choices, such as stock volatility and firm profitability.

\section{A. Main Testable Hypotheses}

Corporate leverage is a natural place to examine the impact of financial conservatism on firm policies. Studies such as Opler and Titman (1994) and Hackbarth (2008) show that financial conservatism could manifest itself as lower levels of corporate leverage. Motivated by this evidence, we conjecture that, all else being equal, Republican managers who exhibit greater financial conservatism would choose lower levels of corporate debt.

We also consider the effect of managerial financial conservatism on multiple dimensions of investment policies. First, we conjecture that due to the risks associated with capital investments, all else being equal, Republican managers would invest less in tangible assets. Second, compared to investment in tangible assets, investment in R\&D has higher uncertainty and typically takes longer to generate payoffs. Thus, Republican managers are likely to choose even lower levels of investment in R\&D. Moreover, conditional upon making an investment, Republican managers would prefer safer projects, which, in turn, would generate lower stock return volatility.

Beyond the impact of managers' political orientation on corporate policies, we investigate whether financial conservatism affects firm profitability. We remain agnostic about the impact of conservative policies of Republican managers on firm performance as two opposing forces operate simultaneously. On the one hand, if conservative managers forgo profitable investment opportunities due to their cautious attitudes, it could lead to lower profitability in the long run. On the other hand, if conservative managers cut unnecessary investments in tangible assets or R\&D, it may boost profitability in the short run. Additionally, if some members of the management team are susceptible to overinvestment, possibly due to hubris (Roll (1986)) or overconfidence (Malmendier and Tate (2005)), conservatism of other managers may constrain this tendency, which could benefit the firm and improve its profitability.

To summarize, our key conjecture is that firms with Republican managers would have lower levels of corporate debt than firms with non-Republican managers. Furthermore, firms with Republican managers would invest less in tangible assets and R\&D and choose safer investments. These policy choices, in turn, may affect firm volatility and profitability. 


\section{B. Managerial Conservatism and Corporate Leverage}

To examine the relation between firm leverage and managers' conservatism, we study four measures of leverage, including the total book debt-to-book assets (TDA), the long-term book debt-to-book assets (LDA), the total book debt-tomarket assets (TDM), and the long-term book debt-to-market assets (LDM).

We begin our empirical analysis by annually sorting firms into three groups identified as low, medium, and high based on the 30th and the 70th percentile breakpoints of firm-level Republican index (REP). For each of the three groups, we average the four industry-adjusted leverage measures for each fiscal year and report the time-series averages of these mean values over the full sample period. The industry-adjusted measure is defined as the difference between the raw measure of leverage and its industry median based on the 4-digit SIC code. We use industry-adjusted rather than raw measures, because Republican managers typically work in industries that have higher leverage. Thus, it is important to eliminate the industry effect in this test.

The sorting results are reported in Table 3. Across the three REP groups, all industry-adjusted leverage measures (TDA, LDA, TDM, and LDM) decrease monotonically. The mean difference in TDA between the high and the low REP groups is $-0.942 \%$, which is highly significant based on the bootstrapped $t$-statistic $(=-6.36)$. The differences in other leverage measures are economically larger and also statistically significant. These sorting results are consistent with our conjecture that firms with Republican managers have less debt.

\section{TABLE 3}

Variable Sorts Based on Firm-Level Political Orientation

Table 3 reports the average political orientation, leverage, and firm policy measures for firms sorted by the Republican index (REP). REP is defined using the political orientation of the firm's top five managers. Each fiscal year, we sort firms into three groups (low, medium, and high) based on the 30th and 70th percentile REP breakpoints. REPCEO is the Republican index based on contributions of firm CEOs. Total debt-to-assets ratio (TDA), long-term debt-to-assets ratio (LDA), total debt-to-market value of assets ratio (TDM), and long-term debt-to-market value of assets ratio (LDM) are industry adjusted by subtracting the median value of the industry based on a 4-digit SIC code. INV is the rate of investment in tangible capital, R\&D is research and development to total assets, VOL is the daily return volatility, and ROA is return on assets. For each variable in each tercile, we first compute the fiscal year mean and then average these mean values across the full sample period. We report the bootstrapped $t$-statistics in parentheses to test the difference in these time-series means between the high and low REP groups. The sample period is from 1992 to 2008 . Additional details about all variables are available in the Appendix.

\begin{tabular}{|c|c|c|c|}
\hline \multicolumn{4}{|c|}{ REP } \\
\hline Low & Medium & High & Diff (High-Low) \\
\hline
\end{tabular}

Panel A. Firm-Level Political Orientation

\begin{tabular}{|c|c|c|c|c|c|}
\hline $\begin{array}{l}\text { REP } \\
\text { REPCEO }^{\text {REP }}\end{array}$ & $\begin{array}{l}0.000 \\
0.002\end{array}$ & $\begin{array}{l}0.181 \\
0.200\end{array}$ & $\begin{array}{l}0.545 \\
0.792\end{array}$ & $\begin{array}{l}0.545 \\
0.789\end{array}$ & $\begin{array}{r}(41.58) \\
(149.43)\end{array}$ \\
\hline \multicolumn{6}{|c|}{ Panel B. Industry-Adjusted Leverage $(\times 100)$} \\
\hline $\begin{array}{l}\text { TDA } \\
\text { LDA } \\
\text { TDM } \\
\text { LDM }\end{array}$ & $\begin{array}{l}2.398 \\
2.584 \\
3.471 \\
3.172\end{array}$ & $\begin{array}{l}2.393 \\
2.441 \\
2.916 \\
2.570\end{array}$ & $\begin{array}{l}1.456 \\
1.619 \\
1.870 \\
2.016\end{array}$ & $\begin{array}{l}-0.942 \\
-0.965 \\
-1.601 \\
-1.156\end{array}$ & $\begin{array}{l}(-6.36) \\
(-6.71) \\
(-6.09) \\
(-4.31)\end{array}$ \\
\hline \multicolumn{6}{|c|}{ Panel C. Other Firm Policies } \\
\hline $\begin{array}{l}\text { INV } \\
\text { R\&D } \\
\text { VOL } \\
\text { ROA }\end{array}$ & $\begin{array}{r}0.279 \\
0.044 \\
0.032 \\
-0.001\end{array}$ & $\begin{array}{l}0.236 \\
0.028 \\
0.027 \\
0.017\end{array}$ & $\begin{array}{l}0.230 \\
0.025 \\
0.027 \\
0.031\end{array}$ & $\begin{array}{r}-0.049 \\
-0.019 \\
-0.005 \\
0.032\end{array}$ & $\begin{array}{r}(-10.88) \\
(-14.00) \\
(-9.79) \\
(7.26)\end{array}$ \\
\hline
\end{tabular}


Next, we estimate a series of leverage regressions. Our key explanatory variable in leverage regressions is REP. The choice of control variables in the leverage regressions is motivated by Cronqvist et al. (2012) and the prior capital structure literature. Specifically, we include the market-to-book ratio (MB) defined as the market value of assets to book value of assets (i.e., the Tobin's Q), a measure of firm size defined as the logarithm of book assets (LOGAT), and tangibility (TANG) defined as net property, plant, and equipment to total book assets. ${ }^{16}$ To minimize the sensitivity of our results to extreme observations or data errors, we winsorize all firm variables at the 1st and 99th percentile levels. Additional details about all variables are available in the Appendix. The summary statistics for the dependent and independent variables are presented in Panels B and C of Table 2.

We use a panel regression specification that includes year- and industry-fixed effects. ${ }^{17}$ The $t$-statistics are based on standard errors clustered at the firm level. We do not include firm-fixed effects in our regressions, because at this point, our aim is to merely establish a correlation between managerial political orientation and corporate policies. Later, in Section VI, we conduct several tests to address issues related to endogeneity and causality.

We present the leverage regression estimates in Panel A of Table 4. Across all four measures of leverage, we find that REP has a significantly negative coefficient estimate. The REP coefficient estimates are also economically significant. For example, for the TDA measure of leverage, the REP coefficient estimate is $-2.22 \%(t$-statistic $=-2.21)$. The estimate indicates that a 1 -standard-deviation increase in $\mathrm{REP}$ leads to a -0.55 percentage-point reduction $(=-2.22 \% \times 0.249)$ in TDA, or a drop of $2.59 \%$ relative to the mean leverage level, $21.4 \%$. Using the market value of leverage as a scaling variable, the economic impact is larger. For example, the REP coefficient estimate $(-3.98 \%)$ indicates a $5.48 \%$ lower TDM when REP is 1 standard deviation above the mean. In contrast, in unreported tests, we find no systematic differences in policies between firms with Democratic managers and firms with moderate managers.

For robustness, we reestimate the leverage regressions using $\mathrm{REP}_{\mathrm{CEO}}$ constructed using only political contributions of CEOs and obtain economically and statistically significant but slightly weaker results (see Panel B of Table 4). These results indicate that political preferences of CEOs, just like those of other top managers, are correlated with leverage choices of firms.

Taken together, these leverage regression estimates show that compared to firms with Democratic and other non-Republican managers, firms with Republican managers have lower leverage, all else being equal. This evidence is consistent with our broad conjecture that financial conservatism of managers can manifest itself in lower levels of corporate debt.

\footnotetext{
${ }^{16}$ Our results hold if we additionally control for the industry median leverage.

${ }^{17}$ We control for industry-fixed effects based on the 2-digit SIC code, but our results are qualitatively and quantitatively similar if we use the 3 -digit SIC code.
} 
TABLE 4

Corporate Leverage Regression Estimates

Table 4 reports the estimates from leverage regressions. Dependent variables are defined as follows: TDA is the total debtto-book asset ratio, LDA is long-term debt-to-book asset ratio, TDM is the total debt-to-market asset ratio, and LDM is the long-term debt-to-market asset ratio. In Panel A, the key independent variable is the Republican index (REP) defined using the political orientation of the firm's top five managers. In Panel B, the key independent variable is the CEO Republican index (REP $\left.\mathrm{CEO}_{\mathrm{O}}\right)$ defined using only the political orientation of the firm's CEO. All control variables are measured in the prior year. All regressions are panel regressions with year- and industry-fixed effects, where industry is defined using 2-digit $\mathrm{SIC}$ codes. The $t$-statistics reported in parentheses below the coefficients are computed using standard errors corrected for clustering at the firm level. Intercepts are included in all regressions but are unreported. To improve readability, all coefficients are multiplied by 100 . The sample period is from 1992 to 2008 . Additional details about all variables are available in the Appendix.

\begin{tabular}{|c|c|c|c|c|}
\hline \multirow{3}{*}{ Independent Variable } & \multicolumn{4}{|c|}{ Dependent Variable } \\
\hline & TDA & LDA & TDM & LDM \\
\hline & 1 & 2 & 3 & 4 \\
\hline \multicolumn{5}{|c|}{ Panel A. Political Orientation Defined Using the Top Five Managers } \\
\hline REP & $\begin{array}{l}-2.22 \\
(-2.21)\end{array}$ & $\begin{array}{l}-2.21 \\
(-2.39)\end{array}$ & $\begin{array}{l}-3.98 \\
(-3.69)\end{array}$ & $\begin{array}{l}-3.34 \\
(-3.43)\end{array}$ \\
\hline MB & $\begin{array}{l}-1.10 \\
(-7.19)\end{array}$ & $\begin{array}{l}-1.01 \\
(-7.14)\end{array}$ & $\begin{array}{c}-1.90 \\
(-15.44)\end{array}$ & $\begin{array}{c}-1.61 \\
(-14.87)\end{array}$ \\
\hline LOGASSET & $\begin{array}{c}2.51 \\
(13.60)\end{array}$ & $\begin{array}{c}1.99 \\
(12.41)\end{array}$ & $\begin{array}{c}2.63 \\
(12.37)\end{array}$ & $\begin{array}{c}2.13 \\
(12.21)\end{array}$ \\
\hline PROFIT & $\begin{array}{l}-12.54 \\
(-5.17)\end{array}$ & $\begin{array}{l}-8.80 \\
(-4.15)\end{array}$ & $\begin{array}{c}19.67 \\
(-10.68)\end{array}$ & $\begin{array}{l}-14.86 \\
(-9.53)\end{array}$ \\
\hline TANG & $\begin{array}{l}16.81 \\
(8.73)\end{array}$ & $\begin{array}{l}16.84 \\
(9.38)\end{array}$ & $\begin{array}{l}20.33 \\
(9.82)\end{array}$ & $\begin{array}{c}19.67 \\
(10.63)\end{array}$ \\
\hline $\begin{array}{l}\text { Year-Fixed Effects } \\
\text { Industry-Fixed Effects }\end{array}$ & $\begin{array}{l}\text { Yes } \\
\text { Yes }\end{array}$ & $\begin{array}{l}\text { Yes } \\
\text { Yes }\end{array}$ & $\begin{array}{l}\text { Yes } \\
\text { Yes }\end{array}$ & $\begin{array}{l}\text { Yes } \\
\text { Yes }\end{array}$ \\
\hline $\begin{array}{l}\text { No. of obs. } \\
R^{2}\end{array}$ & $\begin{array}{l}24,195 \\
23.89 \%\end{array}$ & $\begin{array}{l}24,195 \\
23.59 \%\end{array}$ & $\begin{array}{l}24,195 \\
28.38 \%\end{array}$ & $\begin{array}{l}24,195 \\
28.06 \%\end{array}$ \\
\hline \multicolumn{5}{|c|}{ Panel B. Political Orientation Defined Using CEOs Only } \\
\hline REPCEO & $\begin{array}{l}-0.98 \\
(-1.73)\end{array}$ & $\begin{array}{l}-0.93 \\
(-1.81)\end{array}$ & $\begin{array}{l}-1.37 \\
(-2.19)\end{array}$ & $\begin{array}{l}-1.10 \\
(-1.98)\end{array}$ \\
\hline Controls and Fixed Effects & Yes & Yes & Yes & Yes \\
\hline $\begin{array}{l}\text { No. of obs. } \\
R^{2}\end{array}$ & $\begin{array}{l}21,786 \\
35.19 \%\end{array}$ & $\begin{array}{l}21,786 \\
33.32 \%\end{array}$ & $\begin{array}{l}21,786 \\
35.80 \%\end{array}$ & $\begin{array}{l}21,786 \\
34.91 \%\end{array}$ \\
\hline
\end{tabular}

\section{Managerial Conservatism and Other Corporate Policies}

To gather further support for our conjecture that greater financial conservatism of Republican managers generates more conservative corporate policies, we consider other policy variables as the dependent variable. Specifically, motivated by Hilary and Hui (2009), we consider the following: i) firm investment in tangible assets, as measured by investment in tangible capital (INV); ii) firm investment in intangible assets, as measured by R\&D expenditures scaled by total book assets (R\&D); and iii) the riskiness of corporate investments, as measured by the return volatility (VOL). In addition, we study firm profitability measured by the return on assets (ROA) as one economic outcome of conservative policies. ${ }^{18}$

Again, we first study the relation between REP and these policy variables using univariate sorts. In Table 3, we also report the time-series averages of INV, $\mathrm{R} \& \mathrm{D}, \mathrm{VOL}$, and ROA across the three REP groups used in the leverage sorts.

\footnotetext{
${ }^{18}$ These policy variables are not strongly correlated with each other or the TDA measures (correlations below 0.25 ). This evidence indicates that we are examining distinct aspects of managerial policy choices.
} 
We find that INV, R\&D, and VOL monotonically decrease and ROA monotonically increases with REP. The high-minus-low difference is -0.049 for INV, -0.019 for R\&D, -0.005 for VOL, and 0.032 for ROA, all of which are statistically significant at the $1 \%$ level. The sorting results show that Republican firms have lower investments, lower volatility, but higher profitability.

Next, like the leverage panel regressions, we estimate regressions for all policy variables that include the full set of control variables. Following Hilary and Hui (2009), our set of control variables in these policy regressions includes lagged MB ratio, lagged total book assets, a loss dummy that takes the value of 1 when earnings in the prior year are negative, and lagged leverage. Similar to our leverage regressions, we estimate panel regressions with both year- and industry-fixed effects and report $t$-statistics obtained using standard errors clustered at the firm level.

The estimates from main investment policy regressions are reported in Table 5. Consistent with our key conjecture, we find that REP has a strong negative association with INV, R\&D, and VOL policy variables. In each case, the REP estimate is both economically and statistically significant. For instance, the coefficient estimate of REP in the INV regression is $-2.49 \%$ ( $t$-statistic $=-2.83$ ).

TABLE 5

Regression Estimates Using Other Corporate Policies

\begin{tabular}{|c|c|c|c|c|}
\hline \multicolumn{5}{|c|}{$\begin{array}{l}\text { Table } 5 \text { reports the estimates from corporate policy regressions. Dependent variables are } \\
\text { rate of investment in tangible capital, R\&D is research and development to total assets, VC } \\
\text { ROA is return on assets. In Panel A, the key independent variable is the Republican index (R } \\
\text { orientation of the firm's top five managers. In Panel B, the key independent variable is the CEC } \\
\text { defined using only the political orientation of the firm's CEO. All control variables are meas } \\
\text { gressions are panel regressions with year- and industry-fixed effects, where industry is def } \\
\text { The } t \text {-statistics reported in parentheses below the respective estimates are computed using } \\
\text { clustering at the firm level. Intercepts are included in all regressions but are unreported. To } \\
\text { cients are multiplied by 100. The sample period is from } 1992 \text { to 2008. Additional details ab } \\
\text { in the Appendix. } \\
\text { Dependent Variable }\end{array}$} \\
\hline \multirow[b]{2}{*}{ Independent Variable } & INV & $R \& D$ & VOL & $\mathrm{ROA}$ \\
\hline & 1 & 2 & 3 & 4 \\
\hline \multicolumn{5}{|c|}{ Panel A. Political Orientation Defined Using Top Five Managers } \\
\hline REP & $\begin{array}{l}-2.49 \\
(-2.83)\end{array}$ & $\begin{array}{l}-1.38 \\
(-4.85)\end{array}$ & $\begin{array}{l}-0.27 \\
(-5.82)\end{array}$ & $\begin{array}{l}2.46 \\
(5.20)\end{array}$ \\
\hline MB & $\begin{array}{c}2.32 \\
(19.90)\end{array}$ & $\begin{array}{c}0.55 \\
(8.99)\end{array}$ & $\begin{array}{c}0.09 \\
(10.84)\end{array}$ & $\begin{array}{c}0.92 \\
(6.21)\end{array}$ \\
\hline LOGASSET & $\begin{array}{c}-1.81 \\
(-14.45)\end{array}$ & $\begin{array}{l}-0.34 \\
(-5.31)\end{array}$ & $\begin{array}{c}-0.29 \\
(-31.00)\end{array}$ & $\begin{array}{c}0.64 \\
(5.00)\end{array}$ \\
\hline LOSS & $\begin{array}{l}-1.19 \\
(-3.05)\end{array}$ & $\begin{array}{c}3.46 \\
(13.70)\end{array}$ & $\begin{array}{c}1.13 \\
(31.51)\end{array}$ & $\begin{array}{l}-13.89 \\
(-24.63)\end{array}$ \\
\hline LAGTDA & $\begin{array}{l}-9.84 \\
(-8.54)\end{array}$ & $\begin{array}{l}-3.58 \\
(-7.70)\end{array}$ & $\begin{array}{c}0.28 \\
(3.30)\end{array}$ & $\begin{array}{l}-3.46 \\
(-3.25)\end{array}$ \\
\hline $\begin{array}{l}\text { Year-Fixed Effects } \\
\text { Industry-Fixed Effects }\end{array}$ & $\begin{array}{l}\text { Yes } \\
\text { Yes }\end{array}$ & $\begin{array}{l}\text { Yes } \\
\text { Yes }\end{array}$ & $\begin{array}{l}\text { Yes } \\
\text { Yes }\end{array}$ & $\begin{array}{l}\text { Yes } \\
\text { Yes }\end{array}$ \\
\hline $\begin{array}{l}\text { No. of obs. } \\
R^{2}\end{array}$ & $\begin{array}{l}23,674 \\
32.23 \%\end{array}$ & $\begin{array}{l}23,674 \\
39.76 \%\end{array}$ & $\begin{array}{l}23,100 \\
51.77 \%\end{array}$ & $\begin{array}{l}23,625 \\
21.69 \%\end{array}$ \\
\hline \multicolumn{5}{|c|}{ Panel B. Political Orientation Defined Using CEOs Only } \\
\hline REPCEO & $\begin{array}{l}-1.30 \\
(-3.28)\end{array}$ & $\begin{array}{l}-0.65 \\
(-3.92)\end{array}$ & $\begin{array}{l}-0.09 \\
(-3.06)\end{array}$ & $\begin{array}{c}1.25 \\
(4.96)\end{array}$ \\
\hline Controls and Fixed Effects & Yes & Yes & Yes & Yes \\
\hline $\begin{array}{l}\text { No. of obs. } \\
R^{2}\end{array}$ & $\begin{array}{l}21,373 \\
32.11 \%\end{array}$ & $\begin{array}{l}21,373 \\
39.88 \%\end{array}$ & $\begin{array}{l}21,062 \\
52.03 \%\end{array}$ & $\begin{array}{l}21,373 \\
22.06 \%\end{array}$ \\
\hline
\end{tabular}


The estimate implies that a 1-standard-deviation increase in REP leads to a $2.44 \%$ reduction in the capital investment levels relative to the mean. Similarly, our other estimates suggest a $10.11 \%$ reduction in $R \& D$ and a $2.32 \%$ reduction in the return volatility when there is a 1-standard-deviation increase in REP. In contrast, for the ROA regression, the coefficient estimate of REP is $2.46 \%$, which represents a $44 \%$ increase in profitability for a 1-standard-deviation increase in REP. These results support our conjecture that conservative managers are associated with conservative investment policies, which lead to lower return volatility and higher profitability.

Similar to the leverage regressions, we reestimate all policy regressions using an alternative measure of firm-level political orientation based on the Republican leaning of CEOs. These results are presented in Panel B of Table 5. We find that in all policy regressions, the estimates of $\mathrm{REP}_{\mathrm{CEO}}$ retain the expected sign and are economically and statistically significant.

Taken together, the results from our baseline policy regressions strongly support our main conjecture that firms with Republican managers adopt more conservative investment policies. These Republican firms invest less in tangible assets, in $\mathrm{R} \& \mathrm{D}$, and choose less risky projects. The conservative corporate policies appear beneficial to shareholders, as reflected by higher profitability. However, conservative corporate policies may dampen long-run firm growth and innovation due to lower investment in tangible assets and $\mathrm{R} \& \mathrm{D}$. Thus, financial conservatism of Republican managers has potential benefits as well as potential costs for the shareholders.

\section{The Causal Influence of Managerial Conservatism}

Our results so far demonstrate a strong correlation between managers' political conservatism and conservative firm policies. Our interpretation is that conservative managers imprint their personal preferences on firm policies through both active and passive channels. If certain types of firms and industries seek out conservative managers to implement or maintain conservative policies, managerial conservatism would influence corporate policies in a passive or compliant manner. Indeed, we find that managers with a strong Republican orientation are more likely to work for firms with similar political corporate and local cultures. In addition, when managers switch jobs, they also tend to move to firms with similar political environments. We present the evidence for the passive influence of managerial conservatism on corporate policies in the Online Appendix.

In this section, we focus on the impact of managerial preferences through the active channel. Specifically, we conduct causality tests to establish the direct role of Republican managers in implementing conservative policies. Our identification strategy focuses on natural experiments in which firms react to exogenous shocks either to their macroeconomic environment or their management team. In these instances, managers are likely to play an active role and adjust firm policies in response to the shocks. When shocks to firms are exogenous and simultaneous, differences in their policy responses can be attributed to differences in managerial style, once we control for other firm characteristics that may affect the response. 
These are sharper tests of causality compared to other approaches, such as firmfixed effects and change-on-change regressions, which we examine later.

\section{A. Event-Based Causality Tests}

We use two aggregate macroeconomic shocks in our causality tests: the Sept. 2001 terrorist attacks (hereafter 9/11) and the Sept. 2008 collapse of Lehman Brothers. In these tests, we focus on changes in firm investment policies rather than leverage policies due to severe constraints on external capital markets, which limited managers' ability to adjust capital structure in response to the shock. Later, we examine changes in leverage around managerial turnovers where such marketwide financial constraints do not apply.

\section{Policy Changes after the $9 / 11$ Attacks}

The 9/11 event represents a clearly exogenous shock to the marketplace that generated a high degree of uncertainty. Our conjecture is that following this aggregate rise in uncertainty, conservative managers, and CEOs in particular, are likely to cut investments more than other managers. We focus on investment in tangible assets (INV) because it is less sticky than investment in R\&D and can be changed more easily in response to an environmental shock.

Specifically, we examine changes in INV (i.e., $\Delta \mathrm{INV}$ ) over two and three quarters after the event, with the first quarter starting in Sept. 2001 or later. To ensure that the policy changes are made by the CEO employed by the firm prior to 9/11, we exclude firms with CEO turnover during 2001 and 2002. We regress the quarterly $\triangle \mathrm{INV}$ on the CEO-level Republican index $\left(\mathrm{REP}_{\mathrm{CEO}}\right)$ together with changes in the control variables. We additionally control for past market-to-book ratio, logarithmic book assets, and profitability, as well as the industry-fixed effects, to account for the possibility that some industries (i.e., airlines) may be more severely affected. We report $t$-statistics obtained using standard errors clustered at the industry level.

We report the results from investment change regressions in columns 1 and 2 of Table 6 . Consistent with our conjecture, we find that firms headed by the Republican CEOs reduce investments by an average of $0.76 \%$ ( $t$-statistic $=-2.57)$ per quarter more during the first two quarters after $9 / 11$, or $14 \%$ on an annual basis relative to the mean pre-9/11 level of $21.55 \%$, as compared to other firms. During the first three quarters, the difference in reduction in INV is $-0.66 \%$ ( $t$-statistic $=-2.79)$ per quarter between the two groups of firms. In unreported tests, we find that the investments remain significantly lower for Republican-leaning CEOs for at least four quarters after the 9/11 attack. In other words, under the reasonable assumption that firm CEOs make important investment decisions during the times of extreme market uncertainty, our evidence suggests that managers' political orientation has a direct impact on firm investment policies.

\section{Policy Changes after the Lehman Brothers Collapse}

We use the bankruptcy of Lehman Brothers in Sept. 2008 as the second natural experiment to test the causal impact of managerial conservatism on corporate policies. Lehman Brothers was a prominent financial services firm that filed for Chapter 11 bankruptcy protection on Sept. 15, 2008. This filing was the largest 
TABLE 6

Investment Change Regression Estimates

Table 6 reports the estimates from regressions that examine investment changes after the $9 / 11$ terrorist attacks and the Lehman Brothers collapse in Sept. 2008. The dependent variable is the change in tangible capital investment rate (INV) during the first two (three) quarters starting from Sept. 2001 or 2008. The key independent variable is the CEO Republican index (REPCEO) defined using only the political orientation of the firm's CEO. All regressions exclude firms with CEO turnovers during the event year and the following year. The control variables are expressed as changes or levels lagged by one quarter. Industry-fixed effects are based on the 2-digit SIC code. Intercepts are included in all regressions but are unreported. To improve readability, all coefficients are multiplied by 100 . The $t$-statistics reported in parentheses below the respective estimates are computed using standard errors corrected for clustering at the industry level. Additional details about all variables are available in the Appendix.

Dependent Variable: $\Delta \mathrm{INV}$

\begin{tabular}{|c|c|c|c|c|}
\hline \multirow[b]{4}{*}{ Independent Variable } & \multicolumn{4}{|c|}{ Dependent vallable: $\Delta$ IINV } \\
\hline & \multicolumn{2}{|c|}{ 9/11 Attacks } & \multicolumn{2}{|c|}{ Lehman Brothers Collapse } \\
\hline & Two Quarters & Three Quarters & Two Quarters & Three Quarters \\
\hline & 1 & 2 & 3 & 4 \\
\hline REPCEO & $\begin{array}{l}-0.76 \\
(-2.57)\end{array}$ & $\begin{array}{l}-0.66 \\
(-2.79)\end{array}$ & $\begin{array}{l}-0.35 \\
(-2.41)\end{array}$ & $\begin{array}{l}-0.23 \\
(-2.14)\end{array}$ \\
\hline$\Delta \mathrm{MB}$ & $\begin{array}{c}0.01 \\
(0.62)\end{array}$ & $\begin{array}{c}0.01 \\
(0.43)\end{array}$ & $\begin{array}{l}-0.09 \\
(-1.52)\end{array}$ & $\begin{array}{l}-0.05 \\
(-1.15)\end{array}$ \\
\hline$\Delta$ LOGASSET & $\begin{array}{c}-0.11 \\
(-0.92)\end{array}$ & $\begin{array}{l}-0.07 \\
(-0.74)\end{array}$ & $\begin{array}{c}0.16 \\
(2.08)\end{array}$ & $\begin{array}{c}0.14 \\
(2.35)\end{array}$ \\
\hline$\Delta \mathrm{LOSS}$ & $\begin{array}{l}-0.10 \\
(-0.41)\end{array}$ & $\begin{array}{l}-0.20 \\
(-1.20)\end{array}$ & $\begin{array}{l}-0.23 \\
(-1.19)\end{array}$ & $\begin{array}{l}-0.15 \\
(-1.25)\end{array}$ \\
\hline$\Delta$ LAGTDA & $\begin{array}{l}-1.48 \\
(-1.49)\end{array}$ & $\begin{array}{l}-1.46 \\
(-2.00)\end{array}$ & $\begin{array}{l}-0.38 \\
(-0.35)\end{array}$ & $\begin{array}{l}-0.47 \\
(-0.58)\end{array}$ \\
\hline $\mathrm{MB}$ & $\begin{array}{c}0.03 \\
(0.38)\end{array}$ & $\begin{array}{c}0.00 \\
(0.06)\end{array}$ & $\begin{array}{c}0.07 \\
(1.38)\end{array}$ & $\begin{array}{c}0.04 \\
(1.25)\end{array}$ \\
\hline LOGASSET & $\begin{array}{c}0.15 \\
(0.98)\end{array}$ & $\begin{array}{c}0.09 \\
(0.87)\end{array}$ & $\begin{array}{l}-0.05 \\
(-1.30)\end{array}$ & $\begin{array}{l}-0.01 \\
(-0.52)\end{array}$ \\
\hline PROFIT & $\begin{array}{c}0.09 \\
(0.37)\end{array}$ & $\begin{array}{c}0.03 \\
(0.16)\end{array}$ & $\begin{array}{l}-0.17 \\
(-1.53)\end{array}$ & $\begin{array}{l}-0.16 \\
(-2.03)\end{array}$ \\
\hline Industry-Fixed Effects & Yes & Yes & Yes & Yes \\
\hline $\begin{array}{l}\text { No. of obs. } \\
R^{2}\end{array}$ & $\begin{array}{r}2,100 \\
11.94 \%\end{array}$ & $\begin{array}{l}3,140 \\
8.52 \%\end{array}$ & $\begin{array}{l}2,318 \\
6.76 \%\end{array}$ & $\begin{array}{l}3,453 \\
4.78 \%\end{array}$ \\
\hline
\end{tabular}

bankruptcy filing in U.S. history, and it generated tremendous uncertainty about the state of the U.S. economy and signaled a massive financial crisis.

Similar to the 9/11 test, we focus on the tangible asset investment rate (INV) and exclude firms with CEO turnover events in 2008 and 2009 to ensure that we capture the decisions made by existing CEOs. We report the coefficient estimates of investment change regressions in columns 3 and 4 of Table 6 . Consistent with our conjecture, we find that $\mathrm{REP}_{\mathrm{CEO}}$ has a significantly negative coefficient. As compared to firms headed by non-Republican CEOs, the average quarterly reduction in INV of firms run by Republican CEOs is $0.35 \%(t=-2.41)$ greater during the first two quarters and $0.23 \%(t=-2.14)$ greater during the first three quarters that begin after Sept. 2008. In an unreported test, we find that the effect of CEO conservatism on changes in investment is attenuated by the fourth quarter. Overall, our evidence is similar to that of the $9 / 11$ event, confirming our prediction that conservative managers choose more cautious investment policies during times of elevated market uncertainty.

\section{Policy Changes around CEO Turnover}

Since we were unable to study changes in leverage around macroeconomic shocks, we examine them in the context of CEO turnovers where political orientation of the CEO may change, allowing us to isolate the causal impact of 
managerial political values on corporate leverage. We gather 2060 CEO turnovers from the employment histories of ExecuComp managers for the firms in our sample. We identify both the old and the new CEOs around the transition events and define old corporate leverage as the level of leverage observed in the last full fiscal year under the old CEO and the new corporate leverage as the level of leverage in the first full fiscal year under the new CEO.

We estimate regressions of change in corporate leverage ( $\triangle \mathrm{TDA})$ on change in political values between the old and the new CEOs $\left(\triangle \mathrm{REP}_{\mathrm{CEO}}\right)$, while controlling for changes in various firm characteristics used in the leverage regressions in Table 4 as well as the past levels of the market-to-book ratio, logarithm of book assets, and profitability. In other words, while past and current CEO conservatism are likely to be positively correlated, we test whether the change in leverage is due to the change in the degree of CEO conservatism. We also control for the year- and industry-fixed effects and report $t$-statistics based on standard errors clustered at the industry level. We expect the coefficient estimate of $\triangle \mathrm{REP}_{\mathrm{CEO}}$ to be negative if a more conservative CEO chooses lower leverage.

The regression estimates are reported in column 1 of Table 7 . We find that, consistent with our expectations, there is a significant negative relation between $\triangle \mathrm{REP}_{\mathrm{CEO}}$ values. In economic terms, the coefficient estimate of $\triangle \mathrm{REP}_{\mathrm{CEO}}$

\title{
TABLE 7
}

\section{CEO Turnover Regression Estimates}

\begin{abstract}
Table 7 reports the estimates from CEO turnover regressions. The dependent variable is the difference in TDA between the first full fiscal year under the new CEO and the last full fiscal year under the old CEO. TDA is the total book debt-to-total assets ratio. The key independent variable is the change in the CEO Republican index $\Delta$ REPCEO defined using only the political orientation of the firm's CEO. Regression 1 uses the full sample of firms with turnover events. Regression 2 uses the subsample of firms with long-term old CEOs (i.e., with 3 or more years of tenure). Regression 3 excludes the bottom $20 \%$ firms by lagged industry-adjusted 12-month returns. Regression 4 uses firms with turnovers due to the death of the old CEO. The control variables are the corresponding changes or levels lagged by 1 year. Intercepts are included in all regressions but are unreported. For regressions $1-3$, the $t$-statistics reported in parentheses below the respective estimates are computed using standard errors corrected for clustering at the industry level. To improve readability, all coefficients are multiplied by 100 . The sample period is from 1992 to 2008 . Additional details about all variables are available in the Appendix.
\end{abstract}

Dependent Variable: $\triangle T$ TDA

\begin{tabular}{|c|c|c|c|c|}
\hline Independent Variable & $\begin{array}{c}\text { Sample } \\
1 \\
\end{array}$ & $\begin{array}{l}\text { Sample } \\
2 \\
\end{array}$ & $\begin{array}{l}\text { Poor Performers } \\
3 \\
\end{array}$ & $\begin{array}{c}\text { Sample } \\
4 \\
\end{array}$ \\
\hline$\Delta \mathrm{REP}_{\mathrm{CEO}}$ & $\begin{array}{l}-1.31 \\
(-2.53)\end{array}$ & $\begin{array}{l}-1.34 \\
(-2.30)\end{array}$ & $\begin{array}{l}-1.42 \\
(-3.03)\end{array}$ & $\begin{array}{l}-5.09 \\
(-1.45)\end{array}$ \\
\hline$\Delta \mathrm{MB}$ & $\begin{array}{l}-0.36 \\
(-1.28)\end{array}$ & $\begin{array}{l}-0.03 \\
(-0.09)\end{array}$ & $\begin{array}{l}-0.05 \\
(-0.17)\end{array}$ & $\begin{array}{l}-0.71 \\
(-0.31)\end{array}$ \\
\hline$\triangle$ LOGASSET & $\begin{array}{c}1.77 \\
(1.43)\end{array}$ & $\begin{array}{c}0.30 \\
(0.22)\end{array}$ & $\begin{array}{c}1.70 \\
(1.16)\end{array}$ & $\begin{array}{c}8.81 \\
(2.54)\end{array}$ \\
\hline$\triangle \mathrm{PROFIT}$ & $\begin{array}{c}0.61 \\
(0.12)\end{array}$ & $\begin{array}{l}-0.20 \\
(-0.04)\end{array}$ & $\begin{array}{l}-4.26 \\
(-0.63)\end{array}$ & $\begin{array}{l}-33.09 \\
(-1.42)\end{array}$ \\
\hline$\Delta \mathrm{TANG}$ & $\begin{array}{c}5.73 \\
(1.59)\end{array}$ & $\begin{array}{c}4.83 \\
(0.79)\end{array}$ & $\begin{array}{c}8.92 \\
(2.36)\end{array}$ & $\begin{array}{l}-19.43 \\
(-0.49)\end{array}$ \\
\hline $\mathrm{MB}$ & $\begin{array}{c}0.44 \\
(1.88)\end{array}$ & $\begin{array}{c}0.83 \\
(2.76)\end{array}$ & $\begin{array}{c}0.73 \\
(2.01)\end{array}$ & $\begin{array}{c}1.09 \\
(0.77)\end{array}$ \\
\hline LOGASSET & $\begin{array}{l}-0.05 \\
(-0.19)\end{array}$ & $\begin{array}{c}0.05 \\
(0.18)\end{array}$ & $\begin{array}{c}0.08 \\
(0.33)\end{array}$ & $\begin{array}{c}0.06 \\
(0.06)\end{array}$ \\
\hline PROFIT & $\begin{array}{c}0.79 \\
(0.26)\end{array}$ & $\begin{array}{c}2.12 \\
(0.59)\end{array}$ & $\begin{array}{l}-0.79 \\
(-0.18)\end{array}$ & $\begin{array}{l}-38.23 \\
(-2.07)\end{array}$ \\
\hline Year- and Industry-Fixed Effects & Yes & Yes & Yes & No \\
\hline $\begin{array}{l}\text { No. of obs. } \\
R^{2}\end{array}$ & $\begin{array}{l}2,060 \\
6.64 \%\end{array}$ & $\begin{array}{l}1,485 \\
6.82 \%\end{array}$ & $\begin{array}{l}1,597 \\
7.42 \%\end{array}$ & $\begin{array}{c}69 \\
29.45 \%\end{array}$ \\
\hline
\end{tabular}


implies a -1.31 percentage point $(t$-statistic $=-2.53)$ change in corporate leverage when a strongly Republican CEO replaces a non-Republican CEO. The observed reduction in leverage levels can result from an equity issuance, debt retirement, or an increase in retained earnings. In unreported tests, we find that a significant debt retirement drives the leverage reduction around CEO turnover. In contrast, there is little change in equity issuance or retained earnings. ${ }^{19}$

Next, we restrict our sample to firms with long-term old CEOs (i.e., with tenure of 3 or more years) who have time to imprint their personal preferences on firm leverage. Thus, the leverage under the long-term old CEO serves as a good benchmark to test the effect of the new CEO's conservatism. We report the estimates for this subsample in column 2 of Table 7. Again, we observe a negative $(-1.34)$ and significant $(t$-statistic $=-2.30)$ coefficient on $\triangle \mathrm{REP}_{\mathrm{CEO}}$ in regressions with all controls and fixed effects. This evidence shows that leverage is altered when a CEO with a different degree of conservatism takes control of the firm.

Of course, it is possible that the board of directors decides to hire a conservative CEO and implement conservative firm policies when the firm is underperforming. While this concern is partially addressed with controls for the past levels of profitability, we conduct a robustness check by excluding poorly performing firms (i.e., bottom $20 \%$ by lagged industry-adjusted 12-month returns). If our results are mainly driven by these poorly performing firms, where changes of both CEO and firm leverage are necessary, then this test will yield weak results. However, our regression estimates reported in column 3 of Table 7 show stronger results. The coefficient estimate of $\triangle \mathrm{REP}_{\mathrm{CEO}}$ is -1.42 , slightly more negative than that in column $1(=-1.31)$. It also has a stronger $t$-statistic of -3.03 (vs. -2.53). Together, these results indicate that differences in the conservatism levels of CEOs cause differences in firm leverage. ${ }^{20}$

Last, we test for causality using CEO death-induced turnovers. It is reasonable to assume that these events are exogenous to the extent that the succession of the new CEO is less likely to be accompanied by the board's pressure to alter firm policies. We collect a sample of 69 deceased CEOs from ExecuComp and other Internet sources. We reestimate the leverage change regression using this small subset of turnovers and report the estimates in column 4 of Table 7 . Again, we observe a negative coefficient on $\triangle \mathrm{REP}_{\mathrm{CEO}}$. The size of the coefficient $(-5.09)$ is more than threefold larger than that in column 1, suggesting a stronger economic impact of the CEO's conservatism. However, the coefficient is statistically insignificant $(t$-statistic $=-1.45$ ), which is likely due to a small sample size $(N=69)$. Nevertheless, in an exogenous setting, such as the death of a CEO, the

\footnotetext{
${ }^{19}$ In unreported tests, we also study whether changes in INV, R\&D, and VOL are negatively related to $\triangle \mathrm{REP}_{\mathrm{CEO}}$ in the $\mathrm{CEO}$ turnover events. We find negative but statistically insignificant coefficients on $\triangle \mathrm{REP}_{\mathrm{CEO}}$. One possible reason for the weak statistical significance is that a new conservative CEO may find it difficult to reduce investments without deterioration of the firm's growth opportunities. Thus, we rely on our tests of macroshocks to study the causal impact of managerial conservatism on investments.

${ }^{20}$ In unreported tests, we add additional controls for past firm performance using past 1-year industry-adjusted stock returns. The results remain similar and, in fact, are slightly stronger. In other words, our results are not simply driven by poor past performances that cause both changes in firm leverage and CEO conservatism.
} 
evidence suggests that more conservative managers implement more conservative leverage policies. Overall, our results from several event-based tests consistently show that there is a direct influence of managerial political preferences on corporate policies.

\title{
B. Alternative Causality Tests
}

Next, we present results from several additional tests to further demonstrate that the political orientation of corporate managers directly influences corporate policies. While the causality tests using exogenous shocks are likely to be more appropriate, an alternative perspective based on other approaches provides additional robustness.

\section{Firm Fixed-Effects Specifications}

First, we introduce firm-fixed effects in all policy regressions and identify the relation between political orientation and corporate policies by exploiting the time variation in these two sets of variables within a firm. If unobserved firm attributes are constant across time, the REP estimates in these firm fixed-effects regressions would capture only the time variation in firm policies that are likely caused by managers' actions. Thus, the REP estimates in these regressions could allow us to establish, at least partially, a causal relation between managerial political orientation and corporate policies.

The estimates from firm fixed-effects regressions are reported in Panel A of Table 8. Even when we include firm fixed-effects, REP has significant coefficient estimates in leverage (TDA), volatility (VOL), and profitability (ROA)

\section{TABLE 8}

\section{Policy Regression Estimates: Alternative Estimation Methods}

\begin{abstract}
Table 8 reports the estimates from alternative causality tests. Dependent variables are defined as follows: TDA is the total book debt-to-total assets ratio, INV is the rate of investment in tangible capital, R\&D is research and development to total assets, VOL is the daily return volatility, and ROA is return on assets. Panel A reports the policy regression estimates obtained using the firm fixed-effects approach. Panel B presents change-on-change regressions in which all dependent and independent variables are annual changes. Firm years with 0 changes in either REP or the dependent variable are excluded. Panel $\mathrm{C}$ reports the policy regression estimates based on a subsample in which the first 3 firm-years of the new CEO's tenure are excluded. In Panels A and B, the key independent variable is the Republican index (REP) defined using the political orientation of the firm's top five managers. In Panel C, the key independent variable is the CEO Republican index (REPCEO) defined using only the political orientation of the firm's CEO. For TDA regressions of Panels A and C, the control variables are identical to those used in regression 1 in Panel A of Table 4, while for other regressions, the control variables are identical to those in Panel A of Table 5. All regressions are panel regressions with year and firm (Panel A) or industry (Panels B and C) fixed effects, where industry is defined using 2-digit SIC codes. The $t$-statistics reported in parentheses below the respective estimates are computed using standard errors corrected for clustering at the firm level (Panel A) or the industry level (Panels B and C). Intercepts are included in all regressions but are unreported. To improve readability, all coefficients are multiplied by 100 . The sample period is from 1992 to 2008. Additional details about all variables are available in the Appendix.
\end{abstract}

Panel A. Estimates from Firm Fixed-Effects Regressions

Dependent Variable

\begin{tabular}{|c|c|c|c|c|c|}
\hline & \multicolumn{5}{|c|}{ Dependent Variable } \\
\hline & TDA & INV & $R \& D$ & VOL & $\mathrm{ROA}$ \\
\hline Independent Variable & 1 & 2 & 3 & 4 & 5 \\
\hline REP & $\begin{array}{c}-4.05 \\
(-4.25)\end{array}$ & $\begin{array}{c}0.71 \\
(0.94)\end{array}$ & $\begin{array}{c}-0.14 \\
(-0.92)\end{array}$ & $\begin{array}{c}-0.13 \\
(-2.14)\end{array}$ & $\begin{array}{c}1.70 \\
(2.18)\end{array}$ \\
\hline Controls & Yes & Yes & Yes & Yes & Yes \\
\hline Year- and Firm-Fixed Effects & Yes & Yes & Yes & Yes & Yes \\
\hline $\begin{array}{l}\text { No. of obs. } \\
R^{2}\end{array}$ & $\begin{array}{l}24,195 \\
68.38 \%\end{array}$ & $\begin{array}{l}24,195 \\
61.28 \%\end{array}$ & $\begin{array}{l}24,195 \\
83.34 \%\end{array}$ & $\begin{array}{l}23,527 \\
68.97 \%\end{array}$ & $\begin{array}{l}24,195 \\
52.21 \%\end{array}$ \\
\hline
\end{tabular}


TABLE 8 (continued)

Policy Regression Estimates: Alternative Estimation Methods

Panel B. Estimates from Change-on-Change Regressions

\begin{tabular}{|c|c|c|c|c|c|}
\hline & \multicolumn{5}{|c|}{ Dependent Variable } \\
\hline & $\Delta \mathrm{TDA}$ & $\Delta \mathrm{INV}$ & $\Delta \mathrm{R} \& \mathrm{D}$ & $\Delta \mathrm{VOL}$ & $\triangle \mathrm{ROA}$ \\
\hline Independent Variable & 1 & 2 & 3 & 4 & 5 \\
\hline$\Delta \mathrm{REP}$ & $\begin{array}{l}-1.82 \\
(-2.44)\end{array}$ & $\begin{array}{l}-1.60 \\
(-2.30)\end{array}$ & $\begin{array}{c}0.57 \\
(1.58)\end{array}$ & $\begin{array}{l}-0.14 \\
(-2.11)\end{array}$ & $\begin{array}{c}0.19 \\
(0.13)\end{array}$ \\
\hline $\begin{array}{l}\text { Controls (changes on the controls } \\
\text { in Panel A) }\end{array}$ & Yes & Yes & Yes & Yes & Yes \\
\hline Year- and Industry-Fixed Effects & Yes & Yes & Yes & Yes & Yes \\
\hline $\begin{array}{l}\text { No. of obs. } \\
R^{2}\end{array}$ & $\begin{array}{l}9,517 \\
2.11 \%\end{array}$ & $\begin{array}{r}10,024 \\
5.51 \%\end{array}$ & $\begin{array}{l}5,089 \\
2.56 \%\end{array}$ & $\begin{array}{c}9,826 \\
35.02 \%\end{array}$ & $\begin{array}{l}10,025 \\
10.48 \%\end{array}$ \\
\hline
\end{tabular}

Panel C. Estimates Excluding the First 3 Years of CEO Tenure



\begin{tabular}{|c|c|c|c|c|c|}
\hline \multirow{3}{*}{ Independent Variable } & \multicolumn{5}{|c|}{ Dependent Variable } \\
\hline & TDA & INV & $R \& D$ & VOL & $\mathrm{ROA}$ \\
\hline & 1 & 2 & 3 & 4 & 5 \\
\hline REPCEO & $\begin{array}{l}-0.55 \\
(-0.77)\end{array}$ & $\begin{array}{l}-1.33 \\
(-2.68)\end{array}$ & $\begin{array}{l}-0.74 \\
(-3.64)\end{array}$ & $\begin{array}{l}-6.66 \\
(-1.91)\end{array}$ & $\begin{array}{c}1.03 \\
(3.23)\end{array}$ \\
\hline $\begin{array}{l}\text { Controls } \\
\text { Year- and Industry-Fixed Effects }\end{array}$ & $\begin{array}{l}\text { Yes } \\
\text { Yes }\end{array}$ & $\begin{array}{l}\text { Yes } \\
\text { Yes }\end{array}$ & $\begin{array}{l}\text { Yes } \\
\text { Yes }\end{array}$ & $\begin{array}{l}\text { Yes } \\
\text { Yes }\end{array}$ & $\begin{array}{l}\text { Yes } \\
\text { Yes }\end{array}$ \\
\hline $\begin{array}{l}\text { No. of obs. } \\
R^{2}\end{array}$ & $\begin{array}{l}12,556 \\
27.32 \%\end{array}$ & $\begin{array}{l}12,324 \\
32.60 \%\end{array}$ & $\begin{array}{l}12,324 \\
41.48 \%\end{array}$ & $\begin{array}{l}12,234 \\
52.74 \%\end{array}$ & $\begin{array}{l}12,324 \\
21.43 \%\end{array}$ \\
\hline
\end{tabular}

regressions. However, in investment in tangible assets (INV) and R\&D regressions, the coefficient estimates are statistically insignificant. The weaker result can be due to both strong firm-manager matching and low managerial turnover. ${ }^{21}$ Overall, although our results are weaker in two policy regressions, with three policy variables, we find evidence of significant causal relation.

\section{Change-on-Change Regressions}

Next, following Chava, Livdan, and Purnanandam (2009), we use changeon-change regressions to examine the active managerial influence on corporate policies. If unobserved firm attributes that cause firm-manager matching stay constant over time, we can attribute changes in firm policies to an active influence of managers' political conservatism.

We estimate change-on-change regression specifications for all five corporate policies. The main explanatory variable is the annual change in the REP measure. We consider only cases where the annual changes in REP and the policy variable are both nonzero. ${ }^{22}$ In all change-on-change regressions, we account for changes in all control variables used in the baseline specifications. We also include year- and industry-fixed effects.

The change-on-change policy regression estimates are reported in Panel B of Table 8 . We find statistically significant coefficients on REP change in the

\footnotetext{
${ }^{21}$ The panel regressions with both year- and firm-fixed effects capture only the within-firm variation caused by managerial turnover, which occurs infrequently. The potential firm-manager matching also makes it difficult for us to use the Graham, Li, and Qiu (2012) method for separating firm- and manager-fixed effects.

${ }^{22}$ Our results are similar when we condition on the magnitude of REP changes, but the sample size drops significantly.
} 
TDA, INV, and VOL change regressions. These estimates show that when firmlevel conservatism increases, firms experience statistically significant reductions in leverage, investments, and firm risk. The coefficient estimates of $\triangle \mathrm{REP}$ in other policy regressions are statistically insignificant, although the coefficient estimates maintain the expected signs.

Since the policy variables are sticky, they may respond with a delay to changes in managerial political orientation. Consistent with this conjecture, in untabulated results, we find that when we reestimate the change-on-change regressions using 1-year lagged $\triangle \mathrm{REP}$, the results improve. With this specification, the coefficient estimate of $\triangle \mathrm{REP}$ has the expected signs in all policy regressions, and it is statistically significant in all but the $R \& D$ regressions. This evidence indicates that changes in firm-level managerial political orientations directly affect firm profitability, but with a delay.

\section{Excluding Firm-Years with New CEOs}

In the last set of tests, we follow Hirshleifer, Low, and Teoh (2012) and exclude the first 3 years of the new CEO's tenure. This test is motivated by their conjecture that the decisions of the new CEOs may not be independent. CEOs are more likely to make independent decisions after the first few years on the job.

We repeat the baseline regressions from Panel A of Tables 4 and 5 by excluding the first 3 years of CEO tenure. The results are reported in Panel C of Table 8. We find that the coefficient estimate of $\mathrm{REP}_{\mathrm{CEO}}$ maintains its expected sign in all regressions and is statistically significant in four of the five policy regressions. The only exception is the leverage regression, where the coefficient of $\mathrm{REP}_{\mathrm{CEO}}$ is statistically insignificant. This finding is not surprising, as our previous evidence around managerial turnover indicates that the change in leverage occurs mainly during the first year under the new CEO. Overall, our evidence from this test supports the idea that conservative managers adopt conservative investment policies.

\section{Conservatism or Attempts to Seek Political Favors?}

In the last set of tests, we entertain an alternative explanation for our findings, which posits that managers' political contributions may be motivated by their desire to form connections with certain politicians or political parties for the benefit of the firm. Thus, the revealed political preferences of managers may reflect their attempts to "buy" political favors rather than their personal ideologies. In this setting, both managers' political donations and firm policies could be endogenously determined.

Although this is an intuitive conjecture, several pieces of our existing evidence cast doubt on the "political favors" hypothesis. First, we find that over $71 \%$ of managers consistently donate to only one party, rather than opportunistically shifting donations between the two parties. Thus, their political contributions do not appear to be strategic.

Second, we observe that political contributions of managers are small and significantly below the FEC contribution limits. In addition, Groseclose et al. (2000) show that firms are more likely to develop political connections through their lobbying activities rather than their political contributions. 
Third, the political connections hypothesis cannot easily explain why political connections with the Republican Party would generate more conservative firm policies, while connections with the Democratic Party would encourage relatively less conservative policies. ${ }^{23}$ Therefore, the political connections hypothesis cannot fully explain our key result that Republican political values generate more conservative corporate policies.

\section{A. Explicit Controls for Political Connectedness}

In addition to presenting these arguments against the political favors hypothesis, we test it empirically. First, we add a measure of political connections (CONNECT) to the baseline policy regression specifications and reestimate them. The CONNECT measure is based on managers' total contributions to both Republican and Democratic parties and is defined in the Appendix. We also include state-fixed effects to account for possible state-specific differences in political connections.

We find that CONNECT has significant coefficient estimates only in the leverage regression (see Panel A of Table 9), which indicates that the impact of political connections on corporate policies is not strong. More importantly, our

\section{TABLE 9}

\section{Policy Regression Estimates to Address Political Connections}

Table 9 reports the estimates from policy regressions that address the issue of political connections. The dependent variable is one of the five corporate policy variables: TDA is the total book debt-to-total assets ratio, INV is the rate of investment in tangible capital, R\&D is research and development to total assets, VOL is the daily return volatility, and ROA is return on assets. The key independent variable is the Republican index (REP) defined using the political orientation of the firm's top five managers. The specification in Panel A additionally controls for measures of managerial political connectedness (CONNECT) and state-fixed effects. In Panel B, the key independent variable REP is constructed by excluding the contributions to political incumbents. For TDA regressions, the control variables are identical to those used in regression 1 in Panel B of Table 4, while for others, the variables are identical to those in Panel A of Table 5. All regressions are panel regressions with year- and industry-fixed effects, where industry is defined using 2-digit SIC codes. The t-statistics reported in parentheses below the respective estimates are computed using standard errors corrected for clustering at the firm level. Intercepts are included in all regressions but are unreported. To improve readability, all coefficients are multiplied by 100 . The sample period is from 1992 to 2008 . Additional details about all variables are available in the Appendix.

\begin{tabular}{|c|c|c|c|c|c|}
\hline \multirow{3}{*}{ Independent Variable } & \multicolumn{5}{|c|}{ Dependent Variable } \\
\hline & TDA & INV & $R \& D$ & VOL & $\mathrm{ROA}$ \\
\hline & 1 & 2 & 3 & 4 & 5 \\
\hline \multicolumn{6}{|c|}{ Panel A. Estimates with Controls for Political Connectedness and State-Fixed Effects } \\
\hline REP & $\begin{array}{l}-1.99 \\
(-2.19)\end{array}$ & $\begin{array}{l}-1.53 \\
(-2.21)\end{array}$ & $\begin{array}{l}-0.79 \\
(-2.91)\end{array}$ & $\begin{array}{l}-0.21 \\
(-4.59)\end{array}$ & $\begin{array}{c}1.88 \\
(3.99)\end{array}$ \\
\hline CONNECT & $\begin{array}{l}-0.18 \\
(-1.91)\end{array}$ & $\begin{array}{l}0.06 \\
(0.70)\end{array}$ & $\begin{array}{c}0.04 \\
(1.42)\end{array}$ & $\begin{array}{c}0.00 \\
(0.70)\end{array}$ & $\begin{array}{c}0.04 \\
(0.66)\end{array}$ \\
\hline $\begin{array}{l}\text { State-Fixed Effects } \\
\text { Controls and Other-Fixed Effects }\end{array}$ & $\begin{array}{l}\text { Yes } \\
\text { Yes }\end{array}$ & $\begin{array}{l}\text { Yes } \\
\text { Yes }\end{array}$ & $\begin{array}{l}\text { Yes } \\
\text { Yes }\end{array}$ & $\begin{array}{l}\text { Yes } \\
\text { Yes }\end{array}$ & $\begin{array}{l}\text { Yes } \\
\text { Yes }\end{array}$ \\
\hline $\begin{array}{l}\text { No. of obs. } \\
R^{2}\end{array}$ & $\begin{array}{l}23,908 \\
36.02 \%\end{array}$ & $\begin{array}{l}23,593 \\
34.15 \%\end{array}$ & $\begin{array}{l}23,593 \\
43.97 \%\end{array}$ & $\begin{array}{l}23,044 \\
52.94 \%\end{array}$ & $\begin{array}{l}23,593 \\
22.41 \%\end{array}$ \\
\hline
\end{tabular}

\footnotetext{
${ }^{23}$ Prior literature has shown that connections with both Republican and Democratic politicians can provide easier access to debt (Johnson and Mitton (2003), Khwaja and Mian (2005), Claessens, Feijen, and Laeven (2008), and Faccio (2010)), generate higher levels of profitability (Niessen and Ruenzi (2010), Chen, Parsley, and Yang (2014)), and increase firm value (Goldman, Rocholl, and So (2009), Hill, Kelly, Lockhart, and Van Ness (2013)). However, this evidence does not predict that stronger connections with the Republican Party would reduce access to debt, which, in turn, will generate lower leverage and higher profitability.
} 


\begin{tabular}{|c|c|c|c|c|c|}
\hline \multicolumn{6}{|c|}{ TABLE 9 (continued) } \\
\hline \multicolumn{6}{|c|}{ Policy Regression Estimates to Address Political Connections } \\
\hline & \multicolumn{5}{|c|}{ Dependent Variable } \\
\hline & TDA & INV & $R \& D$ & VOL & $\mathrm{ROA}$ \\
\hline Independent Variable & 1 & 2 & 3 & 4 & 5 \\
\hline \multicolumn{6}{|c|}{ Panel B. Estimates Using REP that Excludes Contributions to Incumbents } \\
\hline REP & $\begin{array}{l}-2.91 \\
(-3.40)\end{array}$ & $\begin{array}{l}-1.60 \\
(-2.33)\end{array}$ & $\begin{array}{l}-0.78 \\
(-2.79)\end{array}$ & $\begin{array}{l}-0.19 \\
(-4.22)\end{array}$ & $\begin{array}{c}1.54 \\
(3.20)\end{array}$ \\
\hline $\begin{array}{l}\text { Controls } \\
\text { Year- and Industry-Fixed Effects }\end{array}$ & $\begin{array}{l}\text { Yes } \\
\text { Yes }\end{array}$ & $\begin{array}{l}\text { Yes } \\
\text { Yes }\end{array}$ & $\begin{array}{l}\text { Yes } \\
\text { Yes }\end{array}$ & $\begin{array}{l}\text { Yes } \\
\text { Yes }\end{array}$ & $\begin{array}{l}\text { Yes } \\
\text { Yes }\end{array}$ \\
\hline $\begin{array}{l}\text { No. of obs. } \\
R^{2}\end{array}$ & $\begin{array}{l}24,195 \\
35.10 \%\end{array}$ & $\begin{array}{l}23,674 \\
32.21 \%\end{array}$ & $\begin{array}{l}23,674 \\
39.58 \%\end{array}$ & $\begin{array}{l}23,100 \\
51.68 \%\end{array}$ & $\begin{array}{l}23,674 \\
21.73 \%\end{array}$ \\
\hline
\end{tabular}

political orientation measure REP remains significant in all policy regressions and its significance is not considerably affected by the presence of the political connections measure and state-fixed effects.

\section{B. Excluding Contributions to Incumbents}

In the second approach, we reconstruct REP without managerial contributions to the incumbent politicians and reestimate all policy regressions. This test is motivated by the evidence that company PAC contributions are directed disproportionately toward incumbents (e.g., Milyo, Primo, and Groseclose (2000)) who may deliver greater political favors due to their experience and seniority in political circles (e.g., Snyder (1990)). If managers' personal contributions are attempts to buy political favors, the contributions to incumbents are more likely to reflect those intentions. By excluding those contributions, we can capture the political orientation of managers more accurately. The policy regression estimates reported in Panel B of Table 9 indicate that our results remain similar to the baseline estimates.

\section{Instrumental Variables Regression Estimates}

In our last set of tests, we use the instrumental variables regression framework to rule out the strategic donation-based explanation for our findings. Specifically, we instrument REP with the demographic attributes of the top five managers that are known to correlate with personal political orientation in the general electorate. This set includes the average percentage of female managers (Female), the average age of managers (Age), the minority status of the CEO (Minority), and the military service experience of the CEO (Military). ${ }^{24}$ Although these instrumental variables may play a role in the firm-manager matching process, unlike personal political contributions, they cannot be changed after hiring in response to the changing business needs of the firm. Therefore, the instrumental variable

\footnotetext{
${ }^{24} \mathrm{We}$ are able to collect the minority status and the military service data for 1873 CEOs from various Internet sources. The CEO is assigned a minority dummy of 1 if the CEO is non-White and a military dummy of 1 if the manager served in the Army or Navy in the past.
} 
approach, at least, can address potential concerns about reverse causality where the firm's needs can affect the political tilt of its managerial contributions.

The estimates in our first-stage leverage regression are reported in Panel A of Table 10. As expected, REP is negatively related to the female dummy, the minority dummy, and positively related to age and the military dummy. In other words, female or minority managers are less likely to lean toward Republicans and older or veteran managers are more likely to identify with Republicans, consistent with prior survey evidence on the demographic tilt of the Republican versus Democratic parties. The coefficients are statistically significant.

TABLE 10

Instrumental Variable Regression Estimates

Table 10 reports the two-stage least square (2SLS) estimates of the instrumental variable regressions. Panel A reports the first-stage estimates, where the dependent variable Republican index (REP) is defined using the political orientation of the firm's top five managers. These instruments include the average percentage of female managers (Female), the average age of managers (Age), the minority status of the CEO (Minority), and the military service experience of the CEO (Military), together with all control variables in the second-stage regressions. Panel B reports the second-stage estimates, where the dependent variable is one of the five corporate policy variables: TDA is the total book debt-to-total assets ratio, INV is the rate of investment in tangible capital, $R \& D$ is research and development to total assets, VOL is the daily return volatility, and ROA is return on assets. The key independent variable is the predicted REP from the first-stage regression. For TDA regressions, the control variables are identical to those used in regression 1 in Panel A of Table 4 , while for others, the variables are identical to those in Panel A of Table 5. All regressions are panel regressions with year-and industry-fixed effects, where industry is defined using 2-digit SIC codes. The $t$-statistics reported in parentheses below the respective estimates are computed using standard errors corrected for clustering at the firm level and for the bias induced by the estimated regressor from the first stage. Intercepts are included in all regressions but are unreported. To improve readability, all coefficients are multiplied by 100. The sample period is from 1992 to 2008. Additional details about all variables are available in the Appendix.

Panel A. First-Stage Regressions

\begin{tabular}{|c|c|c|c|c|c|}
\hline \multirow[b]{2}{*}{ Independent Variable } & \multicolumn{5}{|c|}{ Dependent Variable: REP } \\
\hline & 1 & 2 & 3 & 4 & 5 \\
\hline Female & $\begin{array}{l}-0.140 \\
(-3.66)\end{array}$ & $\begin{array}{l}-0.149 \\
(-3.94)\end{array}$ & $\begin{array}{l}-0.149 \\
(-3.94)\end{array}$ & $\begin{array}{l}-0.146 \\
(-3.80)\end{array}$ & $\begin{array}{l}-0.149 \\
(-3.94)\end{array}$ \\
\hline Age $(\times 100)$ & $\begin{array}{c}0.222 \\
(3.44)\end{array}$ & $\begin{array}{r}0.197 \\
(3.06)\end{array}$ & $\begin{array}{c}0.197 \\
(3.06)\end{array}$ & $\begin{array}{c}0.195 \\
(2.99)\end{array}$ & $\begin{array}{r}0.197 \\
(3.06)\end{array}$ \\
\hline Minority & $\begin{array}{l}-0.050 \\
(-1.79)\end{array}$ & $\begin{array}{l}-0.051 \\
(-1.86)\end{array}$ & $\begin{array}{l}-0.051 \\
(-1.86)\end{array}$ & $\begin{array}{l}-0.056 \\
(-2.02)\end{array}$ & $\begin{array}{l}-0.051 \\
(-1.86)\end{array}$ \\
\hline Military & $\begin{array}{c}0.040 \\
(2.40)\end{array}$ & $\begin{array}{c}0.042 \\
(2.45)\end{array}$ & $\begin{array}{c}0.042 \\
(2.45)\end{array}$ & $\begin{array}{c}0.040 \\
(2.33)\end{array}$ & $\begin{array}{c}0.042 \\
(2.45)\end{array}$ \\
\hline $\begin{array}{l}\text { Controls } \\
\text { Year- and Industry-Fixed Effects }\end{array}$ & $\begin{array}{l}\text { Yes } \\
\text { Yes }\end{array}$ & $\begin{array}{l}\text { Yes } \\
\text { Yes }\end{array}$ & $\begin{array}{l}\text { Yes } \\
\text { Yes }\end{array}$ & $\begin{array}{l}\text { Yes } \\
\text { Yes }\end{array}$ & $\begin{array}{l}\text { Yes } \\
\text { Yes }\end{array}$ \\
\hline $\begin{array}{l}\text { No. of obs. } \\
R^{2}\end{array}$ & $\begin{array}{l}18,252 \\
12.01 \%\end{array}$ & $\begin{array}{l}17,908 \\
12.13 \%\end{array}$ & $\begin{array}{l}17,908 \\
12.13 \%\end{array}$ & $\begin{array}{l}17,652 \\
11.92 \%\end{array}$ & $\begin{array}{l}17,908 \\
12.13 \%\end{array}$ \\
\hline
\end{tabular}

Panel B. Second-Stage Policy Regressions

Dependent Variable

\begin{tabular}{|c|c|c|c|c|c|}
\hline & \multicolumn{5}{|c|}{ Dependent Variable } \\
\hline & TDA & INV & $R \& D$ & VOL & $\mathrm{ROA}$ \\
\hline Independent Variable & 1 & 2 & 3 & 4 & 5 \\
\hline Predicted REP & $\begin{array}{l}-1.90 \\
(-0.20)\end{array}$ & $\begin{array}{l}-34.07 \\
(-3.86)\end{array}$ & $\begin{array}{l}-9.93 \\
(-3.35)\end{array}$ & $\begin{array}{l}-3.60 \\
(-5.01)\end{array}$ & $\begin{array}{l}17.50 \\
(3.32)\end{array}$ \\
\hline $\begin{array}{l}\text { Controls } \\
\text { Year- and Industry-Fixed Effects }\end{array}$ & $\begin{array}{l}\text { Yes } \\
\text { Yes }\end{array}$ & $\begin{array}{l}\text { Yes } \\
\text { Yes }\end{array}$ & $\begin{array}{l}\text { Yes } \\
\text { Yes }\end{array}$ & $\begin{array}{l}\text { Yes } \\
\text { Yes }\end{array}$ & $\begin{array}{l}\text { Yes } \\
\text { Yes }\end{array}$ \\
\hline $\begin{array}{l}\text { No. of obs. } \\
R^{2}\end{array}$ & $\begin{array}{l}18,252 \\
23.89 \%\end{array}$ & $\begin{array}{l}17,908 \\
26.86 \%\end{array}$ & $\begin{array}{l}17,908 \\
36.49 \%\end{array}$ & $\begin{array}{l}17,652 \\
41.68 \%\end{array}$ & $\begin{array}{l}17,908 \\
20.90 \%\end{array}$ \\
\hline
\end{tabular}

We then use the predicted REP from the first-stage regression as the key explanatory variable in the second-stage regression, where the dependent variable is one of the five policy/outcome measures. We report the coefficient estimates in 
Panel B of Table 10. The estimates show that, as expected, the predicted REP has a negative coefficient on TDA, INV, R\&D, and VOL and a positive coefficient on ROA. All coefficients are statistically significant at $1 \%$, except for the TDA regression, where the coefficient is insignificant.

In unreported robustness checks, we find that the insignificant coefficient estimate of REP in the TDA regression is due to the fact that female and minority managers are directly associated with lower leverage, despite the fact that these managers tend to lean toward the Democratic Party. This evidence is likely to reflect the risk preferences of female and minority managers that are uncorrelated with their ideologies but correlated with these social identities. Consistent with this interpretation, we find that the coefficient of the predicted REP restores its significance when we use Age as the sole instrument. For other policy variables, the results are robust to various combinations of instrumental variables. Overall, the leverage results are sensitive to the choice of the instruments, while the results with other policy and profitability results are robust.

Based on these findings, we conclude that the attempt to seek political favors is not the primary determinant of the observed relation between political orientation and corporate policies. The empirical evidence is more consistent with our key hypothesis based on political preferences, which posits that managers with conservative personal ideologies choose conservative corporate policies.

\section{Summary and Conclusion}

This paper examines the relation between the personal political orientation of firm managers and corporate policies. Motivated by the evidence from the previous political science and psychology literatures and the theory of behavioral consistency, we conjecture that Republican managers, who are more likely to follow conservative personal ideologies, choose more conservative corporate policies. Although there are Republican managers who choose riskier corporate policies, on average, conservative Republican managers choose more conservative corporate policies than managers with Democratic orientation.

Consistent with our conjecture, we find that firms with Republican managers have lower levels of corporate debt, lower capital and R\&D expenditures, and less risky investments. Furthermore, these policies are associated with lower volatility and higher profitability at least in the short run. While Republican managers are more likely to be employed by firms with conservative political culture, even among those firms, greater managerial conservatism is associated with more conservative policies. These findings are unlikely to reflect the impact of political connectedness on corporate policies, because we continue to find a strong relation between managers' political preferences and firm policies even when we use several proxies to explicitly account for the effects of political connections on corporate policies.

To establish the causal relation between managerial conservatism and corporate policies, we use the 9/11 terrorist attacks and Sept. 2008 Lehman Brothers bankruptcy as natural experiments. We find that corporate investment policies of Republican managers became more conservative following these exogenous uncertainty-increasing events. Furthermore, around managerial turnover, including 
CEO deaths, firm leverage policy becomes more conservative when the current CEO is replaced by a more conservative CEO. Our evidence from several additional causality tests supports the conjecture that managerial conservatism has a direct causal impact on firm policies.

Overall, our results show that the personal political preferences of corporate managers are significant determinants of corporate policies. The impact of these policy choices on firm valuation, however, remains unclear. On the one hand, the cautious policies of Republican managers make firms less risky and more profitable. On the other hand, the choice of lower levels of R\&D due to financial conservatism may dampen innovation and could be costly to shareholders in the long run. Future research can identify which of these two channels has a dominant effect on long-term firm valuation.

\section{Appendix. Variable Definitions}

\section{Political Values of Managers}

Cycle-Specific Manager-Level Republican dummy (REPDUMMGR): A dummy variable that takes a value of 1 if a manager's political contributions in a given election cycle all go to Republican-affiliated candidates or party committees and 0 otherwise. This dummy variable is cycle specific.

Manager-Level Republican index (REPMGR): The mean REPDUMMGR across all election cycles in which the manager makes political contributions.

Firm-Level Republican index (REP): Manager-level Republican indices (i.e., REPMGR) are aggregated to the firm level using weights that are defined as the inverse of managers' pay ranks. Nondonor managers are assigned a REPMGR of 0 during aggregation.

Firm-Level CEO Republican index (REP $\mathrm{CEO}_{\mathrm{O}}$ ): The REPMGR of the CEO of a firm. When there is more than one CEO during a fiscal year, it is the average REPMGR of the CEOs.

Measures of Corporate Leverage and Firm Policies

Total debt-to-assets ratio (TDA): The ratio of total debt (debt in current liabilities (Compustat variable DLC) + long-term debt (DLTT)) to total book assets (AT).

Long-term debt-to-assets ratio ( $L D A)$ : The ratio of long-term debt (DLTT) to total book assets (AT).

Total debt-to-market value of assets ratio (TDM): The ratio of total debt (debt in current liabilities (DLC) + long-term debt (DLTT)) to market value of assets (MVA). MVA is the sum of the market value of equity (price-close (PRCC) $\times$ shares outstanding (CSHPRI)) plus debt in current liabilities (DLC), long-term debt (DLTT), and the liquidation value of preferred stock (PSTKL), minus deferred taxes and investment tax credit (TXDITC).

Long-term debt-to-market value of assets ratio (LDM): The ratio of long-term debt (DLTT) to market value of assets (MVA).

Investment in tangible capital (INV): The ratio of capital expenditure (CAPEX) to total net property, plant, and equipment (PPENT).

Research and development $(R \& D)$ : The ratio of research and development expense (XRD) to total assets (AT). Coded as 0 if missing.

Return volatility $(V O L)$ : The standard deviation of daily stock returns during the calendar year in which the current fiscal year ends. 
Return on assets (ROA): The ratio of income before extraordinary items (IB) to total assets (AT).

\section{Control Variables}

Market-to-book ratio (MB): The ratio of market value of assets (MVA) to total assets (AT), where MVA is the sum of the market value of equity (price-close $(\mathrm{PRCC}) \times$ shares outstanding (CSHPRI)) plus debt in current liabilities (DLC) and long-term debt (DLTT), and the liquidation value of preferred stock (PSTKL), minus deferred taxes and investment tax credit (TXDITC).

Lagged total debt-to-assets ratio (LAGTDA): Total debt-to-assets ratio (TDA) lagged by 1 year.

Log of assets (LOGASSET): The logarithm of total book assets (AT).

Profitability (PROFIT): The ratio of operating income before depreciation (OIBDP) to total assets (AT).

Tangibility (TANG): The ratio of total property, plant, and equipment (net) (PPENT) to total assets (AT).

Loss dummy (LOSS): A dummy that takes a value of 1 if ROA is negative, and 0 otherwise.

Political connectedness (CONNECT): For each manager, we compute the ratio of his total contributions to both Republican and Democratic parties and the median contributions of all managers in the sample in the most recent election cycle. The median contributions deflator accounts for the upward trend in political contributions. Managers who make no political contributions in an election cycle are assigned a value of 0 . We weight the ratios of the top five managers in a fiscal year, where a manager's weight is proportional to the inverse of the manager's pay rank.

\section{References}

Abramowitz, A. I., and K. L. Saunders. "Exploring the Bases of Partisanship in the American Electorate: Social Identity vs. Ideology." Political Research Quarterly, 59 (2006), 175-187.

Ansolabehere, S.; J. M. de Figueiredo; and J. M. Snyder. "Why Is There So Little Money in US Politics?" Journal of Economic Perspectives, 17 (2003), 105-130.

Atieh, J. M.; A. P. Brief; and D. A. Vollrath. "The Protestant Work Ethic Conservatism Paradox: Beliefs and Values in Work and Life." Personality and Individual Differences, 8 (1987), $577-580$.

Benmelech, E., and C. Frydman. "Military CEOs." Journal of Financial Economics, forthcoming (2014).

Bertrand, M., and A. Schoar. "Managing with Style: The Effect of Managers on Firm Policies." Quarterly Journal of Economics, 118 (2003), 1169-1208.

Bonaparte, Y.; A. Kumar; and J. Page. "Political Climate, Optimism, and Investment Decisions." Working Paper, University of Miami. Available at http://ssrn.com/abstract=1509168 (2012).

Cain, M. D., and S. B. McKeon. "CEO Personal Risk-Taking and Corporate Policies." Journal of Financial and Quantitative Analysis, forthcoming (2014).

Chava, S.; D. Livdan; and A. Purnanandam. "Do Shareholder Rights Affect the Cost of Bank Loans?" Review of Financial Studies, 22 (2009), 2973-3004.

Chava, S., and A. Purnanandam. "CEOs versus CFOs: Incentives and Corporate Policies." Journal of Financial Economics, 97 (2010), 263-278.

Chen, H.; D. C. Parsley; and Y. Yang. "Corporate Lobbying and Financial Performance." Working Paper, Vanderbilt University. Available at http://ssrn.com/abstract=1014264 (2014).

Chyz, J. "Personally Tax Aggressive Executives and Corporate Tax Sheltering." Journal of Accounting and Economics, 56 (2013), 311-328.

Claessens, S.; E. Feijen; and L. Laeven. "Political Connections and Preferential Access to Finance: The Role of Campaign Contributions." Journal of Financial Economics, 88 (2008), 554-580.

Conover, P. J., and S. Feldman. "The Origins and Meaning of Liberal/Conservative SelfIdentifications." American Journal of Political Science, 25 (1981), 617-645.

Converse, P. E. The Nature of Belief Systems in Mass Publics. New York: Free Press (1964), 206-261. 
Cooper, M. J.; H. Gulen; and A. V. Ovtchinnikov. "Corporate Political Contributions and Stock Returns." Journal of Finance, 65 (2010), 687-724.

Cronqvist, H.; A. K. Makhija; and S. E. Yonker. "Behavioral Consistency in Corporate Finance: CEO Personal and Corporate Leverage.” Journal of Financial Economics, 103 (2012), 20-40.

Di Giuli, A., and L. Kostovetsky. "Are Red or Blue Companies More Likely to Go Green? Politics and Corporate Social Responsibility." Journal of Financial Economics, 111 (2014), 158-180.

Epstein, S. "The Stability of Behavior: I. On Predicting Most of the People Much of the Time." Journal of Personality and Social Psychology, 37 (1979), 1097-1126.

Faccio, M. "Differences between Politically Connected and Non-Connected Firms: A Cross-Country Analysis." Financial Management, 39 (2010), 905-928.

Funder, D. C., and C. R. Colvin. "Explorations in Behavioral Consistency: Properties of Persons, Situations, and Behaviors.” Journal of Personality and Social Psychology, 60 (1991), 773-794.

Gillies, J., and S. Campbell. "Conservatism and Poetry Preferences." British Journal of Social Psychology, 24 (1985), 223-227.

Glasgow, M. R., and A. M. Cartier. "Conservatism, Sensation-Seeking, and Music Preferences." Personality and Individual Difference, 6 (1985), 393-395.

Goldman, E.; J. Rocholl; and J. So. "Do Politically Connected Boards Affect Firm Value?" Review of Financial Studies, 22 (2009), 2331-2360.

Graham, J. R.; C. R. Harvey; and M. Puri. "A Corporate Beauty Contest." National Bureau of Economic Research Working Paper No. 15906. Available at http://ssrn.com/abstract=1571469 (2010).

Graham, J. R.; C. R. Harvey; and M. Puri. "Managerial Attitudes and Corporate Actions.” Journal of Financial Economics, 109 (2013), 103-121.

Graham, J. R.; S. Li; and J. Qiu. "Managerial Attributes and Executive Compensation.” Review of Financial Studies, 25 (2012), 144-186.

Green, D. P.; B. Palmquist; and E. Schickler. Partisan Hearts and Minds: Political Parties and the Social Identities of Voters. New Haven, CT: Yale University Press (2002).

Groseclose, T.; J. Milyo; and D. Primo. "Corporate PAC Campaign Contributions in Perspective." Business and Politics, 2 (2000), 75-88.

Hackbarth, D. "Managerial Traits and Capital Structure Decisions." Journal of Financial and Quantitative Analysis, 43 (2008), 843-881.

Hilary, G., and K. W. Hui. "Does Religion Matter in Corporate Decision Making in America?" Journal of Financial Economics, 93 (2009), 455-473.

Hill, M. D.; G. W. Kelly; G. B. Lockhart; and R. A. Van Ness. "Determinants and Effects of Corporate Lobbying." Financial Management, 42 (2013), 931-957.

Hirshleifer, D. A.; A. Low; and S. H. Teoh. "Are Overconfident CEOs Better Innovators?" Journal of Finance, 67 (2012), 1457-1498.

Hong, H., and L. Kostovetsky. "Red and Blue Investing: Values and Finance.” Journal of Financial Economics, 103 (2012), 1-19.

Jiang, D.; A. Kumar; and K. Law. "Political Preferences and Analyst Behavior." Working Paper, University of Miami. Available at http://ssrn.com/abstract=1686238 (2014).

Johnson, S., and T. Mitton. "Cronyism and Capital Controls: Evidence from Malaysia." Journal of Financial Economics, 67 (2003), 351-382.

Jost, J. T. "The End of the End of Ideology.” American Psychologist, 61 (2006), 651-670.

Jost, J. T.; J. Glaser; A. W. Kruglanski; and F. J. Sulloway. "Political Conservatism as Motivated Social Cognition.” Psychological Bulletin, 129 (2003), 339-375.

Kam, C. D., and E. N. Simas. "Risk Orientations and Policy Frames." Journal of Politics, 72 (2010), $1-16$.

Kaustia, M., and S. Torstila. "Stock Market Aversion? Political Preferences and Stock Market Participation.” Journal of Financial Economics, 100 (2011), 98-112.

Khwaja, A. I., and A. Mian. "Do Lenders Favor Politically Connected Firms? Rent Provision in an Emerging Financial Market." Quarterly Journal of Economics, 120 (2005), 1371-1411.

Kish, G. B.; E. E. Netterberg; and L. Leahy. "Stimulus-Seeking and Conservatism." Journal of Clinical Psychology, 29 (1973), 17-20.

Malmendier, U., and G. Tate. "CEO Overconfidence and Corporate Investment.” Journal of Finance, 60 (2005), 2661-2700.

Malmendier, U.; G. Tate; and J. Yan. "Overconfidence and Early-Life Experiences: The Effect of Managerial Traits on Corporate Financial Policies.” Journal of Finance, 66 (2011), 1687-1733.

McAllister, P., and A. Anderson. "Conservatism and the Comprehension of Implausible Texts." European Journal of Social Psychology, 21 (1991), 147-164.

Milyo, J.; D. Primo; and T. Groseclose. "Corporate PAC Campaign Contributions in Perspective." Business and Politics, 2 (2000), 75-88. 
Niessen, A., and S. Ruenzi. "Political Connectedness and Firm Performance: Evidence from Germany." German Economic Review, 11 (2010), 441-464.

Opler, T. C., and S. Titman. "Financial Distress and Corporate Performance." Journal of Finance, 49 (1994), 1015-1040.

Roll, R. "The Hubris Hypothesis of Corporate Takeovers." Journal of Business, 59 (1986), 197-216.

Snyder, J. M. "Campaign Contribution as Investments: The House of Representatives, 1980-1986." Journal of Political Economy, 98 (1990), 1195-1227.

Wilson, G. D. "A Dynamic Theory of Conservatism." In The Psychology of Conservatism, G. D. Wilson, ed. London: Academic Press (1973), 257-265.

Zelizer, J. E. "The Forgotten Legacy of the New Deal: Fiscal Conservatism and the Roosevelt Administration, 1933-1938." Presidential Studies Quarterly, 30 (2000), 331-358. 